\title{
Resources, production, and income on eastern West Virginia beef cattle farms
}

\author{
Alfred L. Barr \\ G. E. Toben \\ Charles C. Wilson
}

Follow this and additional works at: https://researchrepository.wvu.edu/ wv_agricultural_and_forestry_experiment_station_bulletins

\section{Digital Commons Citation}

Barr, Alfred L.; Toben, G. E.; and Wilson, Charles C., "Resources, production, and income on eastern West Virginia beef cattle farms" (1967). West Virginia Agricultural and Forestry Experiment Station Bulletins. 546.

https://researchrepository.wvu.edu/wv_agricultural_and_forestry_experiment_station_bulletins/500 
West Virginia University Libraries

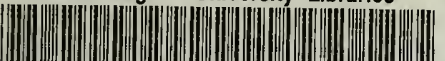
30802100952134 308021009521343 



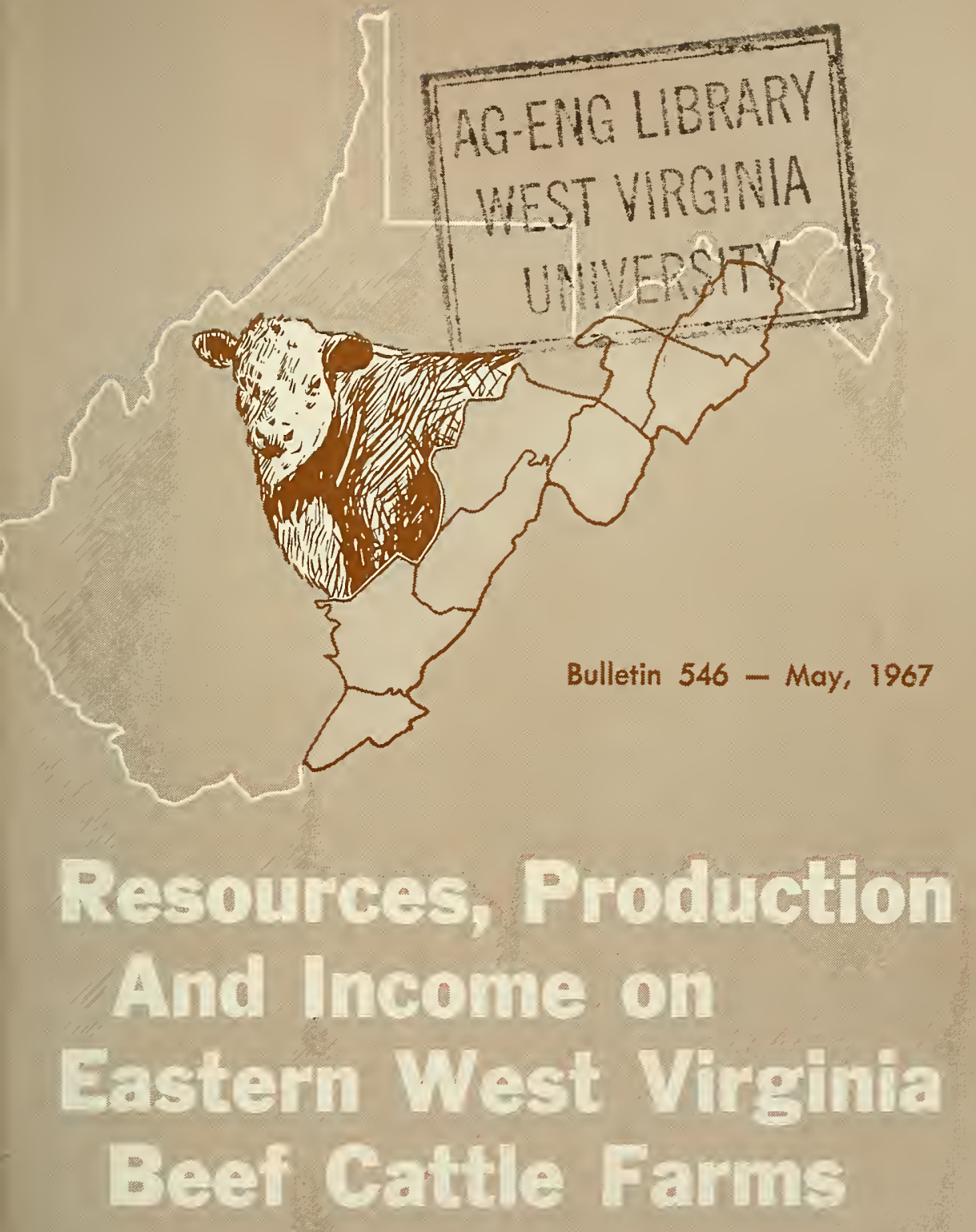

\section{West Virginia University} Agriculfural Experiment Station 
Digitized by the Internet Archive in 2010 with funding from

Lyrasis Members and Sloan Foundation 


\section{Resources, Production, And Income on Eastern West Virginia Beef Cattle Farms}

Alfred L. Barr, George E. Toben, and Charles C. Wilson, Jr.

\section{West Virginia University} Agricultural Experiment Station 


\section{The Authors}

Alfred L. Barr is Associate Agricultural Economist: George E. Toben is Agricultural Economist; and Charles C. Wilson, Jr., at the time of this study, was a Graduate Research Assistant.

\section{Acknowledgments}

The authors wish to acknowledge contributions of the County Agricultural Extension Agents who assisted in the selection of the farms in the sample; the farmers who provided the data on their farming operations; Mr. Ernest Goff who worked diligently in the collection of the clata; and Mr. James H. Clarke, Mr. Joseph Emch, Dr. Keith Inskeep, and Dr. G. G. Pohlman who read the manuscript and made many valuable suggestions and criticisms.

WEST VIRGINIA UNIVERSTT

Agricultural. Experiment Station

College of Agriculture and Forestry

A. H. Vanlandingham, Director

MORG.ANTOWN 


\section{CONTENTS}

Summary and Conclusions $\ldots \ldots \ldots \ldots \ldots \ldots \ldots$

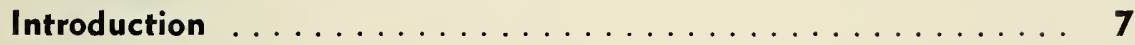

Description of the Area $\ldots \ldots \ldots \ldots \ldots \ldots$

Land Use on Selected Farms $\ldots \ldots \ldots \ldots \ldots \ldots$

Livestock on Selected Farms ................20

Land Required Per Animal Unit on Farms ............. 29

The Average Farm: Its Resources, Production, and Income ... 29

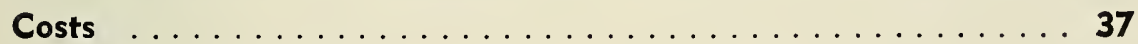

Returns to Labor and Investment . . . . . . . . . . . 42

Bibliogrophy $\ldots \ldots \ldots \ldots \ldots \ldots \ldots \ldots \ldots \ldots \ldots \ldots$ 



\section{SUMMARY AND CONCLUSIONS}

Between 1950 and 1964 both the price and quantity of inputs used by farmers in the United States increased. The combined effect of increased purchases and increased prices was a 75 per cent increase in expenditures by farmers for inputs. During the same period, prices received by farmers for products sold declined by 9 per cent. Thus, to retain the same level of income as they had in 1950, farmers were forced to increase production. United States farmers met this challenge in two ways: (1) increasing their output per unit of input and (2) enlarging the size of their business.

During the years 1930 to 1964 , the number of beef cows in West Virginia increased while other classes of livestock, excluding poultry, declined. The growth in number of beef cows would inclicate that farmers who raise beef cattle have made adjustments by increasing the volume of resources used and output.

This study was designed to determine the extent to which adjustments have occurred on farms specializing in feeder-calf production in West Virginia. A selected sample of farmers was interviewed in an eight-county area of eastern West Virginia.

Farms in the study averaged 124 acres of cropland and about 431 acres of pasture land. An average of 46 per cent of the upland pasture and 83 per cent of the bottom land pasture had been treated or improved by some method.

The average herd consisted of 67 brood cows, 20 replacement heifers, and three bulls. The sample farms averaged a 91 per cent calf crop with four per cent of the cows not calving in a 12-month period and 5 per cent of the calves dying before weaning. About 40 per cent of the calves weaned were sold in the fall and the remaining 60 per cent were kept for either replacements or further feeding and future sales.

In addition to the beef breeding herd, the study farms had 32 animal units of feecler cattle, 11 animal units of sheep and approximately five animal units of horses, clairy cattle, and goats. There was an average of 133 animal units of forage-consuming livestock on the selected farms.

The major crop in terms of acreage produced on the sample farms was hay. There were 77 acres per farm and the average yield was 2.1 tons. Silage was harvested on 77 of the sample farms with an average of 267 tons of silage produced in 1963. Total hay equivalents fed on the sample farms averaged 219 tons or 1.6 tons per animal unit. About 4.2 acres of land were being used per animal unit for crops and pasture. 
With the current average size herd-67 cows-the returns to labor and investment are estimated to be $\$ 21.45$ per cow or $\$ 1,437$ for the herd.

If all forage produced on the farms in the study would have been used by a cow-calf enterprise, an average of 109 cows could have been maintained with the performance levels of 1963-1964, and returns to labor and investment would have been $\$ 2,338$. To achieve a $\$ 3,000$ return to investment, labor, and management, 135 cows or twice the present average size herd would be required. 


\section{Resources, Production,}

And Income on

\section{Eastern West Virginia} Beef Cattle Farms'

\section{Alfred L. Barr, George E. Toben, and Charles C. Wilson, Jr.}

B EEF PRODUCERS are receiving lower prices for the products they sell and are paying higher prices for the increased quantities of items they must buy. Changes and adjustments have been made by the producers, but more are required.

The quantity of purchased farm inputs rose by 25 per cent from 1950 to 1964 (Figure 1). This increase was due to the replacement of unpaid family labor by machinery, to the replacement of farm grown feeds by purchased feeds and the purchase of fuel to provide power, to the substitution of commercial fertilizers for manure and land, and to the increased use of such other items as insecticides, herbicides, and pesticides.

There was also a 40 per cent increase in the price of purchased inputs, which when combined with increased quantities of purchased inputs, resulted in an estimated overall increase of 75 per cent in expenditures for purchased inputs. ${ }^{*}$ The increase in physical quantities accounts for 38 per cent of the total increase and inflation accounts for the other 62 per cent of the increase.

During the period 1950-1964, prices received for farm products were below 1950 levels, except for the years of 1951 and 1952. For this entire period the prices farmers received, adjusted to 1950 purchasing power, averaged 96 per cent of the 1950 level, but prices and volumes of purchased inputs increased. Thus, not only were clollars buying less, but from a given level of output there were fewer dollars for the increased buying at higher prices. 


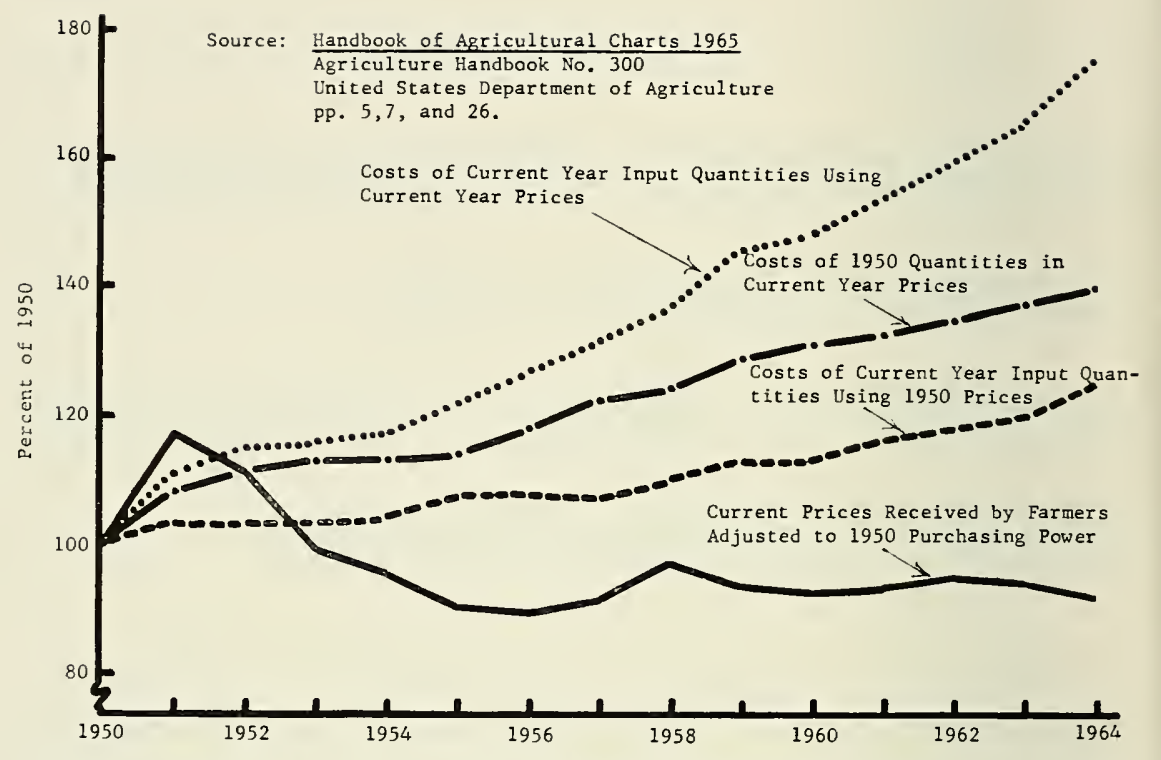

Figure 1. Costs of non-farm origin inputs and prices received by farmers, United States, 1950-1964.

To meet the price-cost squeeze, farmers, as a group, enlarged the size of their businesses in order to spread costs over a larger number of output units. Farmers not only applied more purchased inputs and intensified land use, but also purchased land and extensively enlarged their enterprises. The result of this expansion on U.S. farms is clearly indicated in Table 1 , and particularly noticeable is the 41 per cent increase in acreage per farm between 1950 and 1959. In West Virginia, farm size increased by 37 per cent in the same 10 -year period.

The number of beef cows in West Virginia increased during the years 1930 to 1964, while other classes of livestock, other than poultry,

TABLE 1

Acreage of land per farm, United States, 1900 to 1959 *

\begin{tabular}{|c|c|c|}
\hline Year & & Number of Acres \\
\hline 1900 & & 147 \\
\hline 1910 & 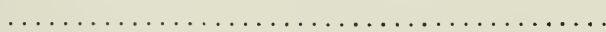 & 138 \\
\hline 1920 & $\ldots \ldots \ldots \ldots \ldots \ldots \ldots \ldots \ldots \ldots \ldots \ldots \ldots \ldots \ldots$ & 148 \\
\hline 1930 & . & 157 \\
\hline 1940 & 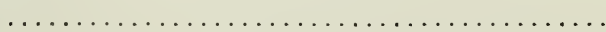 & 174 \\
\hline 1950 & 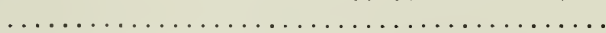 & 215 \\
\hline 1959 & $\ldots \ldots \ldots \ldots \ldots \ldots \ldots \ldots \ldots \ldots \ldots \ldots \ldots \ldots \ldots$ & 303 \\
\hline
\end{tabular}

*U. S. Bureau of Census. U. S. Census of A!rriculturc: 1959, Vol. II, Gcneral Report, p. 445 . 
decreased (Table 2). Large changes in numbers of beef cows, milk cows, sheep, and hogs occurred between 1950 and 1959. The pronounced, six-fold increase in number of beef cows in the 35 years while numbers of other livestock were declining, indicates that adjustments have been made to enable West Virginia farmers to meet the increased costs and declining prices. There is further indication that farmers with beef cows have become more competitive as they have increased farm size and number of cattle. Because of these changes, this study was designed to:

1. Determine the availability and use of land resources on beef cattle farms in West Virginia.

2. Determine the beef cattle resources presently on these farms.

3. Determine the resulting output from this combination of land and cattle.

4. Determine the income from the beef cow-calf enterprise.

To accomplish these objectives, data were collected from a sample of farms in counties where beef production is relatively important. The farms included in the sample for this study were a selected group -not randomly chosen-of above average beef producers for whom beef was, and probably would be in the future, an important source of income.

\section{TABLE 2}

\section{Numbers of livestock, other than poultry, in the study area and West Virginia, by selected census periods*}

\begin{tabular}{|c|c|c|c|c|c|c|c|}
\hline \multirow[b]{2}{*}{ Year } & & \multicolumn{3}{|c|}{ PEEF COWS $\% *$} & \multicolumn{3}{|c|}{ MILK COWS } \\
\hline & & State & $\begin{array}{l}\text { Study } \\
\text { Area } * * \% *\end{array}$ & $\begin{array}{l}\text { Portion in } \\
\text { Study Area }\end{array}$ & State & $\begin{array}{l}\text { Study } \\
\text { Area }\end{array}$ & $\begin{array}{l}\text { Portion in } \\
\text { Study Area }\end{array}$ \\
\hline & & Number & Number & Per Cent & Number & Number & Per Cent \\
\hline 1930 & & 28,605 & 8,982 & 31.4 & 183,263 & 23,458 & 12.8 \\
\hline 1940 & & 35,958 & 12,082 & 33.6 & 218,769 & 32,159 & 14.7 \\
\hline 1950 & $\ldots \ldots \ldots$ & 82,667 & 26,619 & 32.2 & 203,997 & 37,943 & 18.6 \\
\hline 1959 & $\ldots \ldots \ldots$ & 141,864 & 44,687 & 31.5 & 121,151 & 24,472 & 20.2 \\
\hline \multirow[t]{2}{*}{1964} & $\ldots \ldots \ldots$ & 180,632 & 54,374 & 30.1 & 83,895 & 24,516 & 29.2 \\
\hline & & & SHEEP & & & HOGS & \\
\hline 1930 & & 576,747 & 200,708 & 34.8 & 221,681 & 45,223 & 20.4 \\
\hline 1940 & $\ldots \ldots \ldots$ & 437,381 & 164,893 & 37.7 & 171,765 & 36,242 & 21.1 \\
\hline 1950 & & 421,700 & 203,681 & 48.3 & 197,286 & 51,689 & 26.2 \\
\hline 1959 & & 290,449 & 167,589 & 57.7 & 148,238 & 47,733 & 32.2 \\
\hline 1964 & $\ldots \ldots$ & 194,932 & 119,240 & 61.2 & 77,971 & 27,988 & 35.9 \\
\hline
\end{tabular}

* Source: United States Census of Agriculture: 1930. Vol. II, Part II, pp. 314 and 338 ; 1940. Vol. I, Part 3, p. $240 ; 1950$. Vol. I, Part 15, p. 390; 1959. Vol. I, Part 25, p. 147. Preliminary Report, 1964.

* * Beef cows including heifers that have calved.

*** Study area numbers, except 1964, are calculated from work done by K. E. Bailey, Some Changes in West Virginia Farming between 1929 and 1959, p. 30 ff. Unpublished report. 
The principal types of animals sold on selected farms were feeder calves, yearlings, or two-year-olds. Farms for which registered animals constituted a large portion of sales were excluded. A minimum herd size of 50 cows or 50 yearlings or a combination of 50 cows and yearlings was required for inclusion in the sample." Older farmers, those in poor health, and those planning retirement within three years were excluded unless a family member was likely to carry on the business. Three visits were made to each farm-the first in June 1963, the second in the following winter, and the third in June 1964. Information obtained inclucted current numbers of livestock, production and sales of livestock, total acres of land in farming, crop acreages, and crop production.

The 101 farmers meeting the requirements for the study were judiged to be above average in management of their enterprises. Even the lowest levels of performance on these farms may be above the average of all operators.

Inputs required to produce a level of income from a beef cow-calf enterprise were determined by budgeting a model farm comparable in size and composition to the study farms.

\section{Description of the Area}

The eight counties in which the 101 farms are situated are in the eastern part of the State (Figure 2). They range from Hampshire in the north to Monroe in the south.

\section{CLIMATE}

The climatic variations within such a small area are chiefly the result of differences in local topography which includes plateaus, mountains, and regions with deep narrow valleys. Elevations include the highest point in the State, Spruce Knob at 4,860 feet, and a low of 520 feet at the Potomac River in Hampshire County. ${ }^{*}$

Rainfall ranges from 25 inches, for a 20 -year average at Upper Tract, Pendleton County, to 69 inches, for a 37 -year average at Pickens in neighboring Randolph County." The normal estimated average precipitation is 42 inches based on the period 1931 to 1960 . Between 50 and 60 per cent of the precipitation normally falls during the growing season, April through September. Between 25 and 30 per cent falls

${ }^{3}$ Records were obtained and used for a few herds of slightly fewer than 50 cows when the county extension agent indicated that the productivity was exceptionally good and that income from the smaller herd would equal or exceed that normally expected from a herd of 50 cows.

${ }^{4}$ West Virginir Gcological Survey. Vol. 10, 1938. p. 12.

climate and Man. Yearbook of Agriculture, 1941. p. $1182-1190$. 


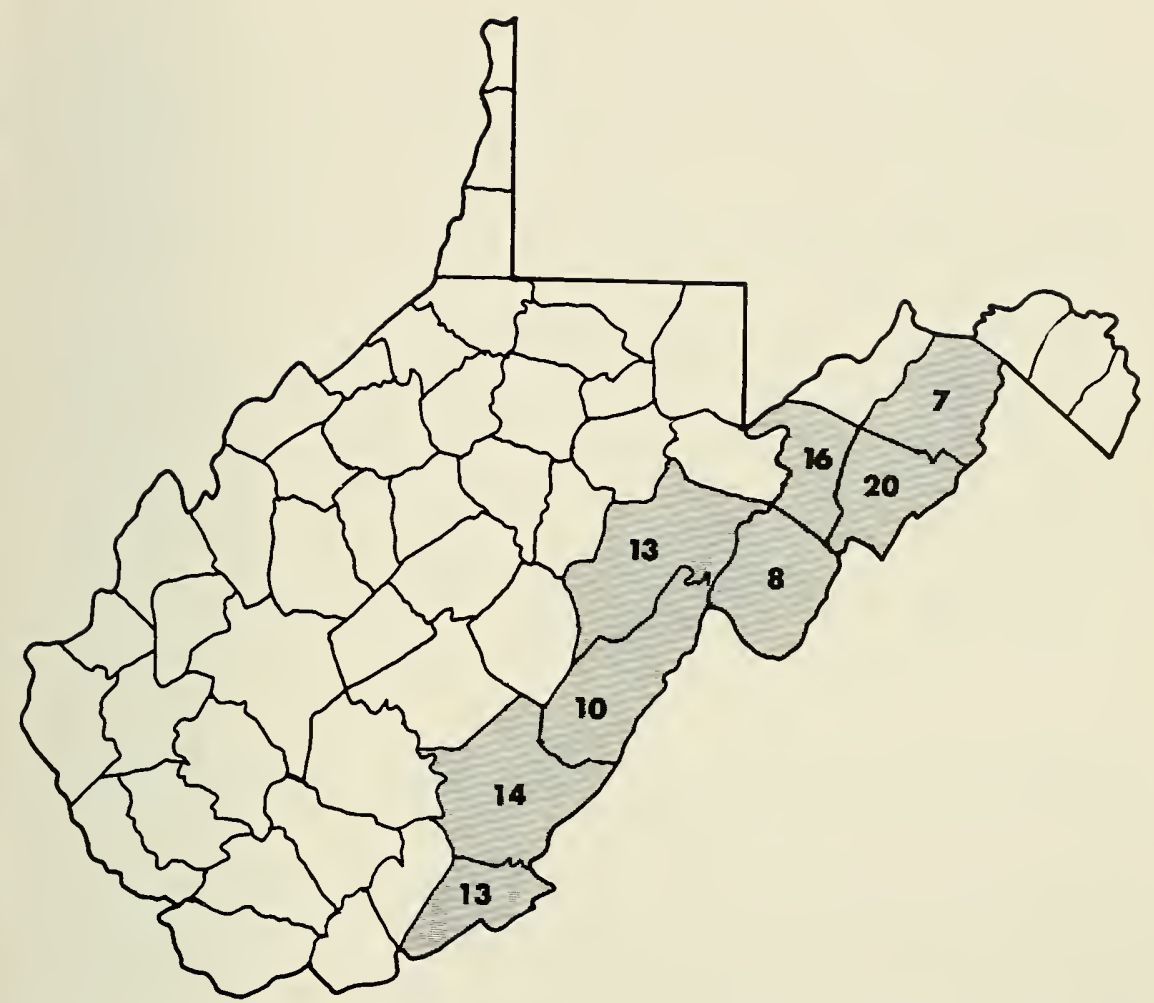

Figure 2. Location of eight counties and number of farms in each included in the study (total-101 farms).

during the months of June, July, and August. ${ }^{6}$ However, these months are warmer and have a higher rate of evaporation.

During the years 1961 to 1965 , between 15 and 35 per cent of the precipitation was during the months of June, July, and August. In the 196I-1965 period the study area had below normal precipitation, with an estimated average of three inches-or 7 per cent-per year below normal during the six months of the growing season (April-September).

The typical growing season varies between 150 and 165 days for the entire area. There are small pockets where the length of growing season is considerably shortened, by elevation and exposure, to as little as 120 days. The July temperature average within the area is from 68 to 74 degrees. Winds are westerly.' Thus, where topography permits, the area is suitable for agriculture to the limits of soil fertility and allowable degree of erosion. 


\section{SOIL}

A study completed in 1937 divides the State into four slope classes. This division of the land by percentage of the State's total land area is shown in Table 3. Corresponding figures were determined for the study area. Although much of the study area would seem rough for farming, it has a higher per cent of the more gentle slopes than does the State as a whole.

The State has been evaluated by means of a Land-Capability Classification system (Table 4). Limitations on use and risk of soil damage increase from Class I through Class VIII. In general, Classes I-IV are used with varying degrees of management for tilled crops. Classes VIVII are suitable for native regetation. Class VIII is land so rough, shallow, or rocky that it will not return benefits in excess of inputs.

Comparison of the data in Table 3 and Table 4 for the State and the study area indicates that the study area is typical of the State in

\section{TABLE 3}

Relative distribution of land, by slope classification, West Virginia and the study area*

\begin{tabular}{|c|c|c|c|}
\hline \multirow[b]{2}{*}{ Slope } & & \multicolumn{2}{|c|}{ Total Land Area } \\
\hline & & West Virginia & Study Area \\
\hline \multicolumn{4}{|c|}{ Per Cent } \\
\hline $0-12$ & $\ldots \ldots$ & 16 & 20 \\
\hline $12-25$ & $\cdots \cdots$ & 18 & $\overline{2} \overline{1}$ \\
\hline $25-10$ & $\ldots$ & 38 & 31 \\
\hline Over 40 & $\ldots \ldots$ & 28 & 29 \\
\hline
\end{tabular}

TABLE 4

Distribution of land classes for West Virginia and the study area*

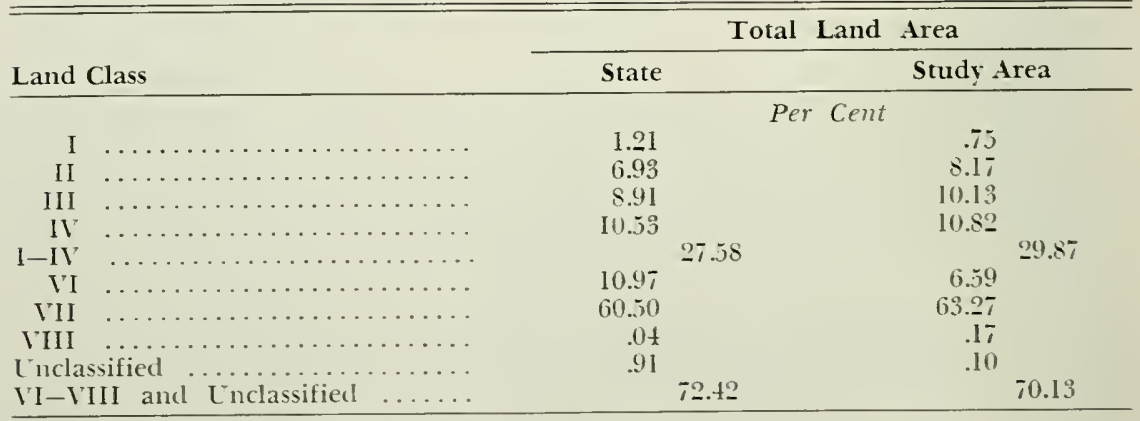

* Source: Computed from Trest Tirginin soit and Water Conscrention veeds Intentory. 1951. p. 123 and 124 . 
both topography and land class. Although much of the land in the study area is rough, rocky, and of low productivity, it does have a slightly higher per cent of land suitable for crop production, capability Classes I-IV, than does the State as a whole.

The Soil Conservation Service of the United States Department of Agriculture divides the study area between two land resource areas. These are the Southern Appalachian Ridges and Valleys and the Eastern Allegheny Plateau and Mountains. The two areas cross state boundaries and are divided by the Allegheny Front ${ }^{s}$ (Figure 3). Within the study area these two major land resource areas are further divided into six smaller land resource areas. ${ }^{9}$ The Southern Appalachian Ridges and Valleys area includes the sub-areas known as Potomac Ridge and Valley area, Allegheny Mountains, Greenbrier Limestone Valley, and Southern West Virginia Shale Ridges. The Eastern Allegheny Plateau and Mountains area includes parts of those counties west of the Allegheny Front and in the Chestnut Ridge Plateau and Raleigh-Fayette Plateau land resource areas.

DeKalb-Lehew soil associations form the largest part of these areas. They are soils formed from sandstone and characterized as generally shallow to moderately deep and steep. ${ }^{10}$ In addition, depending on the association, they are mostly stony soils, largely covered with forest, and include a few gentle slopes for farming. ${ }^{11}$ Litz-Calvin soils, spreading widely through the area, form another large association. They are characterized as shallow or very shallow, well drained soils having low moisture holding capacity and inherently moderate fertility. WeikertBerks (Ashby) soil associations are characterized as being shallow and steep, mostly forested with low available moisture capacity, very low inherent fertility, and originating from hard acid shale. ${ }^{12}$

The Hagerstown-Frankstown-Frederick soil association forms the largest continuous section of good farming land and is found in the south central region of Pocahontas County, central region of Greenbrier County and north-central region of Monroe County. The soils of this association are all deep, well drained soils with high moisture holding capacity. Hagerstown and Frederick soils have high inherent fertility, while Frankstown has moderately high inherent fertility. They are all derived from limestone, with Frederick coming from cherty limestone and Frankstown from inpure limestone.

s"Land Resource Regions and Major Land Resource as Areas of the United States," A.ricultural Handbook 296, 1965. Enclosed map.

${ }^{9}$ Land Resource Hap of West Virginia. USDA Soil Conservation Service, 1958.

in B. J. Patton, A Brief Description of the Major Soils of West Virginia, 1955. p. $1 \mathrm{ff}$.

${ }^{11}$ Lrind Resource May of West Virginia, USDA, Soil Conservation Service, $195 \mathrm{~S}$.

${ }^{12}$ B. J. Patton, op. cit. 


\section{MAJOR SOIL ASSOCIATIONS}

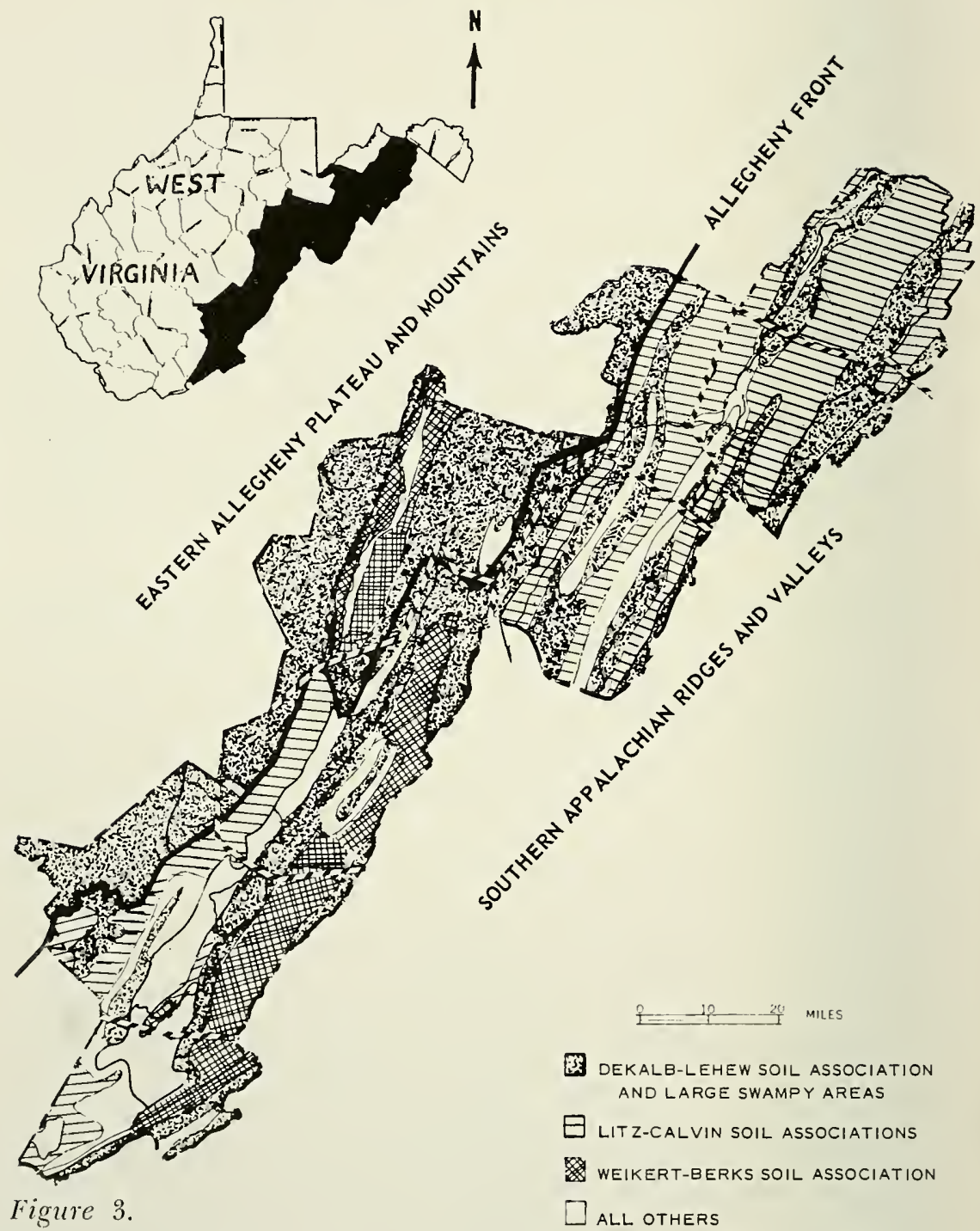

Other soil associations found in the area, but in smaller acreages are: (1) Corydon-Elliber limestone-Corydon is shallow, stony limestone soil; Elliber is deep and a good orchard soil; (2) Huntington, Lindside, and Monongahela-these are bottom land and terrace soils; (3) DunmoreMurrill, and Laidig-these are deep, well drained limestone and sandstone soils with stony areas; (4) Pope, Atkins, Tyler, and Berks soils 
of Tygarts Valley and Leading Creek-Pope soil is well drained and Atkins is poorly drained, both are acid flood plains. Tyler is a poorly drained slack water terrace soil; Berks is a shallow acid soil originating from shale material. ${ }^{13}$

\section{LIVESTOCK}

Because of the limited amount of relatively good cropland, the study area is largely devoted to pasture and forage which is utilized for beef cattle, dairy cattle, and sheep. There are pockets of specialized agricultural production, such as the apple orchards, limited beef feeding and poultry enterprises. The abundance of native grasses on steep slopes and limited production of winter feed has established a grazing agriculture as the farming system of major economic importance for the area.

The 1930-1964 trends of livestock numbers for the study area and the State are shown in Table 2. The decline in numbers of livestock other than beef cows has been at a slower rate in the study area than for the State as a whole. Numbers of beef cows have increased steadily and at about the same rate in the study area as in the State as a whole.

\section{Land Use on Selected Farms}

Land use data on the 101 selected farms of the study area include the total number of acres, upland and bottom land, major crops grown, and pasture land.

The average farm had 555 acres of cropland and pasture. Total acreage of cropland and pasture per farm ranged from 136 to 2,700 acres. Farms in Pocahontas County were the largest and had an average of 796 acres of cropland and pasture while those in Hardy County were the smallest, with an average of 410 acres.

Eighty-three per cent of the land in these farms was classified as upland and the remaining 17 per cent as bottom land. Greenbrier County and Monroe County farms reported little bottom land clue to their plateau type topography. Sample farms in Hardy County had the highest proportion of bottom land (40 per cent).

\section{CROPLAND}

There was an average of 124 acres of cropland per farm (Table 5). The sample farms of Hampshire County had the most cropland-193 acres per farm-and Monroe County farms had the least cropland with 100 acres per farm. 
TABLE 5

Acreage of cropland per farm by upland and bottom land on selected farms, by counties and eight-county area, West Virginia, 1963-1964

\begin{tabular}{|c|c|c|c|c|c|}
\hline County & Farms & Upland & $\begin{array}{c}\text { Bottom } \\
\text { Land }\end{array}$ & $\begin{array}{c}\text { Total } \\
\text { Cropland }\end{array}$ & $\begin{array}{c}\text { Portion in } \\
\text { Bottom Land } \\
\end{array}$ \\
\hline & Number & & Acres & & Per Cent \\
\hline Hampshire & 7 & 115 & 78 & 193 & 40 \\
\hline Hardy ...... & 20 & 19 & 89 & 108 & 82 \\
\hline Grant $\ldots$ & 16 & 48 & 83 & 131 & 63 \\
\hline Pendleton & 8 & 26 & 101 & 127 & 80 \\
\hline Randolph & 13 & 53 & $5 \mathrm{I}$ & 104 & 49 \\
\hline Pocahontas & 10 & 119 & 43 & 162 & 27 \\
\hline Greenbrier & 14 & 118 & 0 & 118 & 0 \\
\hline Monroe & 13 & 94 & 6 & 100 & 6 \\
\hline Eight-County Area & 101 & 68 & 56 & 124 & 45 \\
\hline
\end{tabular}

Approximately 10 per cent of the total cropland area was rented. Twenty-six of 99 farms $^{1+}$ rented 1,355 acres, or an average of 52 acres per farm renting land. The land was rented on either a cash or a share basis and corn and hay were the chief crops grown on it.

\section{Crops Grown}

Corn was grown by 85 of the 99 sample farmers. The number of acres ranged from an average of eight per farm in Randolph County to 43 in Hardy County and averaged 29 on the sample farms (Table 6) . Small grains crops, including wheat, oats, and barley were reported by 75 of the 99 farmers and averaged 14 acres per farm. The sample farms of Ranclolph County produced only four acres of small grains and the farms in Grant County had the most with 20 acres. Wheat and oats were the two most commonly grown small grains, with about equal acreages of each.

Hay crops, which constituted the largest single use of cropland on the sample farms, were grown on an average of 77 acres per farm.

Clover and clover mixtures comprised the largest portion of the hay acreage, 55 per cent, and alfalfa and alfalfa mixtures were next with 42 per cent (Table 7). For the study area, 99 farms averaged 42 acres of clover and clover mixtures and 32 acres of alfalfa and alfalfa mixtures. Oat and grass hays were grown on a very low percentage of the total acreage, and were reported mostly in Hampshire and Hardy counties.

Hay Production and Purchases. On sample farms, for the year the study was made, the yield per acre of harrested hay ranged from 1.3

"Neliable cropland data were obtained from only 99 farmers; thus, the discussion is limiter to 99 rather than 101 farms. 


\section{TABLE 6}

\section{Acreage of specified crops on selected farms, by counties and eight-county area, West Virginia, 1964*}

\begin{tabular}{|c|c|c|c|c|c|}
\hline County & Farms & Corn & $\begin{array}{r}\text { Small } \\
\text { Grains }\end{array}$ & Hay & Total $* *$ \\
\hline & Number & \multicolumn{4}{|c|}{ Acres } \\
\hline Hampshire ....... & 7 & 37 & 11 & 93 & 141 \\
\hline Hardy $\ldots \ldots \ldots \ldots$ & 20 & 43 & 19 & 48 & 110 \\
\hline Grant $\ldots \ldots \ldots \ldots$ & 16 & 37 & 20 & 99 & 156 \\
\hline Pendleton & $7 * *$ & 39 & 9 & 60 & 108 \\
\hline Randolph & $12 * *$ & 8 & 4 & 102 & 114 \\
\hline Pocahontas & 10 & 23 & 17 & 128 & 168 \\
\hline Greenbrier & 14 & 24 & 12 & 54 & 90 \\
\hline Monroe $\quad \ldots \ldots \ldots$ & 13 & 20 & 14 & 63 & 97 \\
\hline Eight-County Area & 99 & 29 & 14 & 77 & 120 \\
\hline
\end{tabular}

* Total acres do not agree with those in Table 5 as this table includes rented land. Table 5 includes all cropland acres with no deduction for soil bank and other production restrictions. A few fields of miscellaneous crops such as sweet corn, beans, and sudex were not included in this Table.

** One farm did not report.

tons in Hampshire County to 2.6 tons in Grant County (Table 8). The average for 101 sample farms was 2.1 tons per acre for all types of hay, which is above the average of 1.2 tons per acre for the area as reported by the State Crop Reporting Service. ${ }^{15}$ This difference reflects the selected sample chosen. Hay harvested per sample farm varied from 91 tons in Hardy County to 253 tons in Grant County; these counties also had the fewest and most animal units per farm, respectively.

The selected farmers purchased an average of six tons of hay. Hardy County farmers purchased almost no hay while Pendleton County farmers bought an average of 14 tons per farm. In the three most mountainous counties, Pendleton, Randolph, and Pocahontas, farmers made the larger purchases of hay.

Silage Production and Storage Capacity. An average of 267 tons of silage was harvested and fed on 77 of the 101 farms included in the study (Table 9). All seven of the farms in Hampshire County harvested silage and their average production was 382 tons. Only four of the 13 farmers interviewed in Randolph County harvested silage, and the four averaged only 85 tons.

There were 183 upright and 39 trench silos on the 77 farms. Average capacity of silos per farm was 337 tons. The 77 farms with silos were using about 79 per cent of their available silage capacity.

${ }^{15} 1964$ West Virginia Agricultural Statistics, Charleston, West Virginia, September, 1964 , p. 13. 


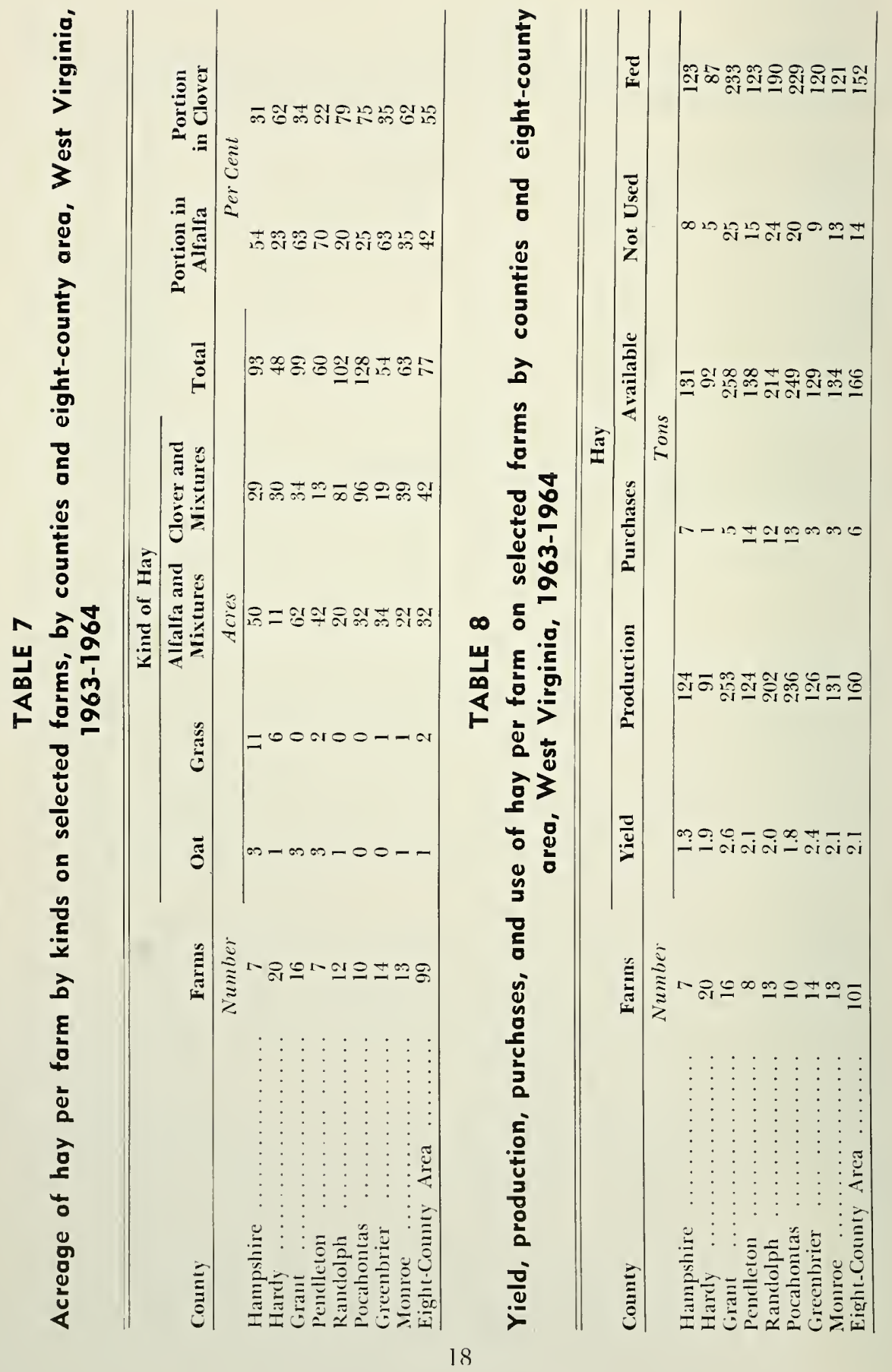




\section{TABLE 9}

Number of silos by type, silage capacity, and silage production on selected farms by counties and eight-county orea, West Virginia, 1963-1964

\begin{tabular}{|c|c|c|c|c|c|c|}
\hline County & $\begin{array}{c}\text { Farms } \\
\text { Having } \\
\text { Silos }\end{array}$ & $\begin{array}{l}\text { Upright } \\
\text { Silos }\end{array}$ & $\begin{array}{l}\text { Trench } \\
\text { Silos }\end{array}$ & $\begin{array}{c}\text { Silo } \\
\text { Capacity } \\
\text { Per Farm }\end{array}$ & $\begin{array}{c}\text { Silage } \\
\text { Per } \\
\text { Farm }\end{array}$ & $\begin{array}{l}\text { Portion of } \\
\text { Capacity } \\
\text { Used }^{1}\end{array}$ \\
\hline & \multicolumn{3}{|c|}{ Number } & \multicolumn{2}{|c|}{ Tons } & PerCent \\
\hline Hampshire & 7 & 20 & 5 & 451 & 382 & 85 \\
\hline Hardy ... & 18 & 34 & 9 & 357 & 284 & 80 \\
\hline Grant $\ldots$ & 13 & 40 & 7 & 449 & 343 & 76 \\
\hline Pendleton & 6 & 12 & i & 267 & 209 & 78 \\
\hline Randolph & 4 & 6 & 2 & 151 & 85 & 56 \\
\hline Pocahontas & 9 & 28 & 3 & 275 & 210 & 76 \\
\hline Greenbrier & 11 & 30 & 4 & 364 & 309 & 85 \\
\hline Monroe $\ldots$ & 9 & 13 & 6 & 203 & 166 & 82 \\
\hline Eight-County Area & 77 & 183 & 39 & 337 & 267 & 79 \\
\hline
\end{tabular}

${ }^{1}$ A part of unused capacity was due to settling of the silage after filling and a part to insufficient forage available on some farms to completely fill the silo capacity.

\section{PASTURE}

The average farm in the study had 431 acres of pasture, of which more than 90 per cent was classified as upland (Table 10). "Pasture land" as defined in this study does not include woodland pasture, but may inclucle wooded sections within some of the pasture areas.

Grant and Pocahontas counties had the largest number of pasture acres per farm, 651 and 634 respectively. Hardy County had the fewest pasture acres per farm, 302 acres.

Approximately 46 per cent of the upland pasture had been improved to some extent (Table 11). The most often used improvement practice was a combination of fertilizer and lime. The frequency of application and quantity of lime and fertilizer used were not ascertained; hence, those acres of pasture which were improved may not be producing at their optimum. Farmers indicated that 47 per cent of the unimproved pasture could be improved with the use of mechanized ground equipment.

The farmers included in the study in Hampshire County improved a higher percentage of their total upland pasture than did the farmers of any other county. Sample farmers in the more rugged counties of Pendleton, Randolph, and Pocahontas had improved a smaller percentage of their pasture than the farmers in the other counties, but they also had a larger number of acres that could not be improved by use of mechanized ground equipment. Sixty-five per cent of the improvable upland pasture on all farms in the study had been improved in some manner. 


\section{TABLE 10}

Acreage of upland and bottom land pasture per farm on selected farms by counties, eight-county area, West Virginia, 1963-1964

\begin{tabular}{|c|c|c|c|c|c|}
\hline County & Farms & Upland & $\begin{array}{c}\text { Bottom } \\
\text { Land }\end{array}$ & Total & $\begin{array}{c}\text { Proportion } \\
\text { Upland }\end{array}$ \\
\hline & Number & & Acres & & Per Cent \\
\hline Hampshire . & 7 & 349 & 39 & 388 & 90 \\
\hline Hardy $\ldots \ldots \ldots \ldots \ldots \ldots$ & 20 & 226 & 76 & 302 & 75 \\
\hline Grant $\quad \ldots \ldots \ldots \ldots \ldots \ldots \ldots$ & 16 & 594 & 57 & 651 & 91 \\
\hline Pendleton & 8 & 523 & 38 & 561 & 93 \\
\hline Randolph & 13 & 281 & 49 & 330 & 85 \\
\hline$\ldots \ldots \ldots \ldots$ & 10 & 613 & 21 & 634 & 97 \\
\hline$\ldots \ldots \ldots \ldots \ldots$ & 14 & 358 & 0 & 358 & 100 \\
\hline 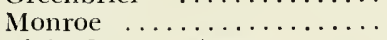 & 13 & 328 & 0 & 328 & 100 \\
\hline Eight-County Area ........ & 101 & 393 & 38 & 431 & 91 \\
\hline
\end{tabular}

A similar analysis of bottom land pasture by management practices, Table 12, shows that about 83 per cent of the bottom land pasture was improved. There was an average of 52 acres of bottom land pasture on the 74 farms, and approximately 43 of the 52 acres had been improved. Farmers reported that seven of the nine unimproved acres of bottom land could have been improved with the use of mechanized ground equipment.

Overall, pasture improvement practices were carried out on 86 per cent of the improvable bottom land pasture and 65 per cent of the improvable upland pasture.

\section{Livestock on Selected Farms}

Livestock on sample farms were divided into four groups for analysis. These were the beef breeding herd, feeder animals, other roughage consuming animals, and non-roughage consuming animals such as hogs and poultry.

\section{BEEF BREEDING HERDS}

The average number of brood cows per herd for the sample farms included in the studly was 67 . This number included 58 cows that had calved at least once prior to the 1963 calving season and nine heifers which were to calve for the first time in 1963 ('Table 13). These numbers represent net figures after allowance for sales, slaughterings, deaths, and purchases. Sample herd averages ranged from 52 cows in Pendleton and Hardy comties to 96 cows in Pocahontas County.

In addition to the 67 brood cows and bred heifers, the sample farms had an average of 23 other beef animals kept for breeding. These were comprised of five two-year-old heifers, nine yearling heifers, six 


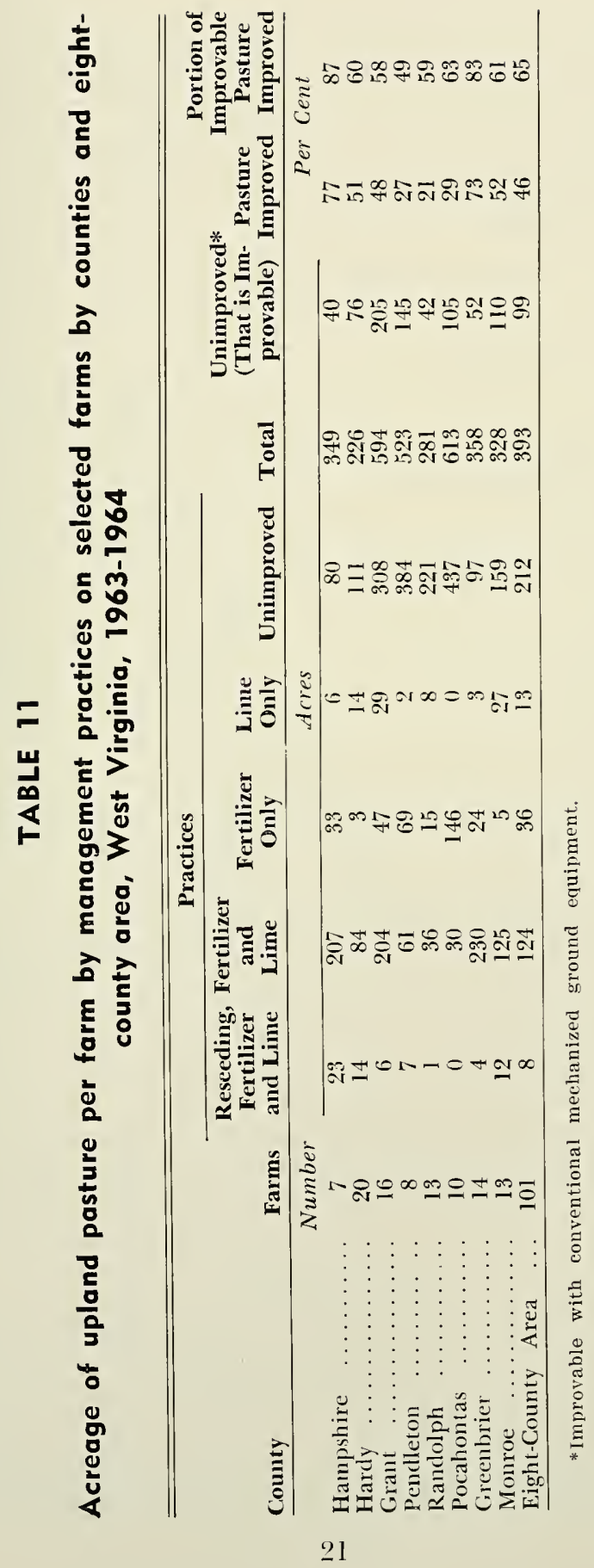




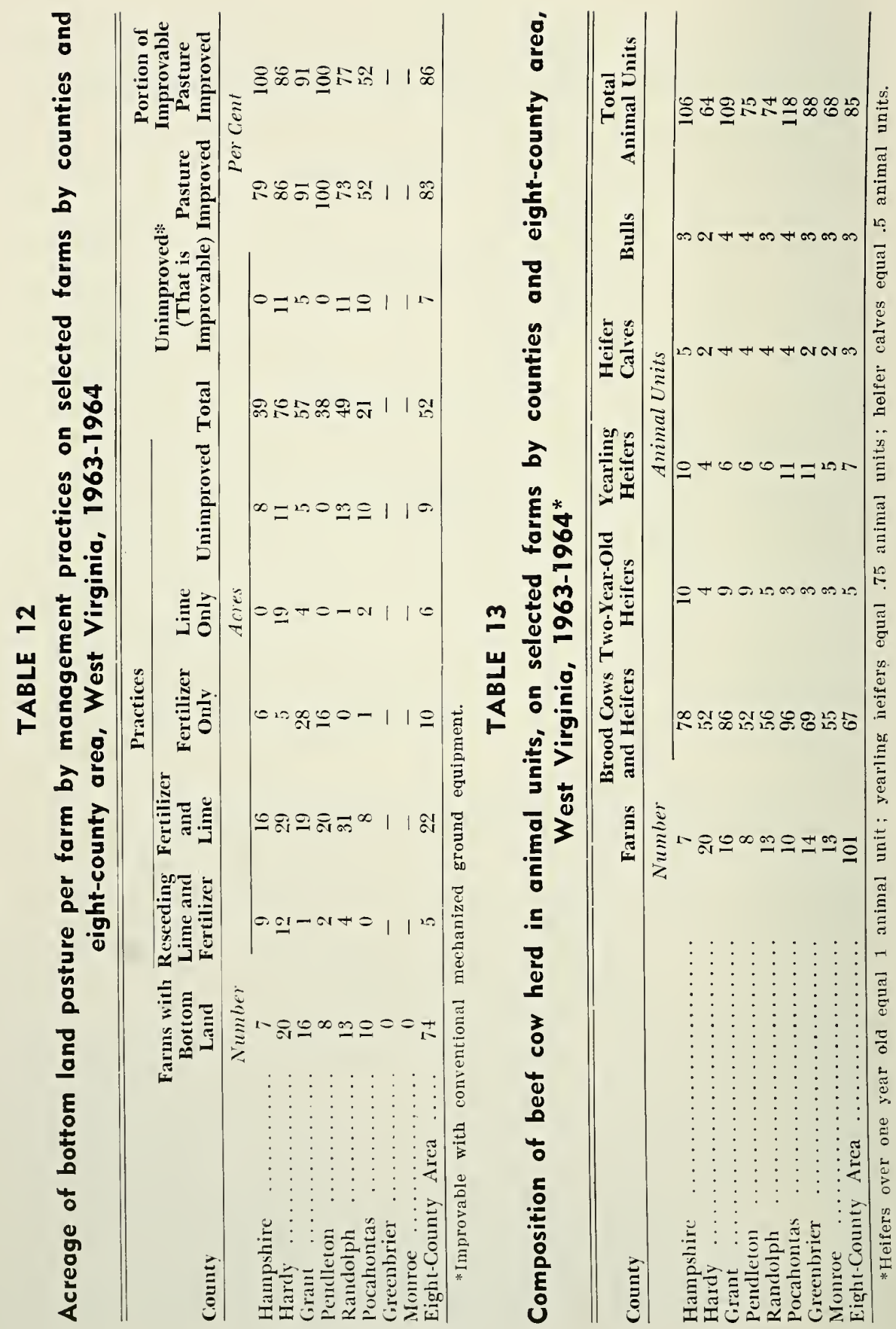


heifer calves, and three bulls. These 23 other beef animals comprised 18 animal units. ${ }^{16}$ Heifers being kept for herd replacements made up 18 per cent of the 82 female animal units in the herd.

\section{REPLACEMENT AND CULLING RATES}

The number of replacements required to maintain a herd of given size is dependent upon the average productive longevity of cows in the herd. The percentage of the herd that was made up of replacements should be an indicator of productivity and of the rate of growth or decline in the size of the herd. But, the replacement figures may be misleacling when a one-year record of an individual farm is considered since many farmers keep more heifers in some years than in others. Many of the sample farms reported keeping no, or very few, replacements in 1963. An average of only six heifer calves was kept for replacements in 1963. This was probably due in part to the drought in that year.

Twenty of the 101 farms reported purchasing a total of 282 cows and heifers, or an average of 2.8 head per farm. Purchases by individual farmers ranged from one to 60 animals. The average of six heifer calves kept for replacement in 1963, plus 2.8 cows and heifers purchased before the calving season in 1964, resulted in less than nine replacements available to offset deaths, sales, and butcherings.

For the average herd of the sample farms about nine beef breeding animals were culled or died during the one-year period. As some of the replacements needed to maintain herd size were also culled or died before entering the herd, the number kept by farmers in the study in this one year was insufficient to maintain constant herd size.

The number of animals dying and sold from the sample farms at various ages during 1963 and 1964 is presented in Table 14. The average age of cows sold was about 10.5 years. Twenty-four per cent of the cows culled or dying were six years old or younger, 18 per cent were seven through 10 years old, 43 per cent were 11 through 14 years old, and 15 per cent were 15 years or older. With a 90 per cent calf crop and an average breeding age of 18 months, each cow had produced about eight calves before being removed from the herd.

\section{CALF CROP}

Data were collected on the number of calves born and the number of calves dying. The number of cows calving was divided by the number of cows exposed to the bull for breeding in order to determine the

\footnotetext{
${ }^{16} 1 \mathrm{n}$ determining the animal unit equivalents, bred replacement heifers, cows, and bulls were assumed to equal one animal unit each. Yearling heifers were assumed to equal .75 animal unit each and heifer calves were assumed to equal .50 animal unit.
} 


\section{Number of cows sold by age groups, and animal years in herds on selected farms, eight-county area, West Virginia, 1963-1964}

\begin{tabular}{|c|c|c|c|}
\hline \multirow{2}{*}{$\begin{array}{l}\text { Age Range } \\
\text { at Sale }\end{array}$} & \multicolumn{2}{|c|}{ Sold or Dying } & \multirow{2}{*}{$\frac{\text { Animal Years* }}{\text { Number }}$} \\
\hline & Number & Per Cent & \\
\hline 3- $6 * * \quad$ & 249 & 24.1 & 1,166 \\
\hline $7-10$ & 187 & 18.1 & 1,580 \\
\hline $11-14$ & 443 & 43.0 & 5,575 \\
\hline $15-18$ & 141 & 13.7 & 2,278 \\
\hline$\ldots \ldots \ldots \ldots \ldots \ldots$ & 11 & I.I & 225 \\
\hline Total $\ldots$ & 1,031 & 100.0 & 10,824 \\
\hline Average*** & & & 10.5 \\
\hline
\end{tabular}
group.

*Animal years were obtained by adding all of the ages of the animals in each age

**As some of the farmers kept heifers to sell as bred heifers, no sales of animals before they reached calving age were included in determining age of cows sold. A larg? per cent of the heifers did not calve until three years old; thus all sales of heifers before they reached three years were excluded.

***The average age of animals leaving the herd was obtained by dividing the total ages of all animals sold and dying by the number of animals sold and dying.

calving percentage. Corrections for sales, multiple births, slaughterings, deaths, and purchases were included. At least 90 per cent of the cows in each of the eight counties of the study weaned a calf in the year between June 1963 and June 1964. Some of the animals which calved may have been repeat breeders and may have thus stretched their production cycle to greater than 12 months, which in turn would reduce the number of calves a cow could produce while in the herd and would lower the calf crop below the 91 per cent reported. The extent to which this occurred could not be detected from information collected. However, the number of cows which had not calved at the time of the visit to the farms in June-8.3 per cent-indicates that repeat breeding may be substantially reducing the actual annual calf crop.

The proportion of cows reported not calving ranged from 2 per cent in Pendleton and Monroe counties to 6 per cent in Pocahontas County (Table 15). The number of calves dying ranged from 4 to 8 per cent of the total calved. ${ }^{17}$ These two factors accounted for the 9 per cent of the cows exposed to a bull for breeding but not raising a calf to market weight. In three of the four counties where the percentage of cows not calving was the lowest (less than 4 per cent) the percentage of calves dying was the highest (more than 5 per cent). Thus, calves weaned per 100 cows did not differ significantly among counties.

${ }^{17}$ Calves dying includes the number of calves born dead and those dying before weaning. 


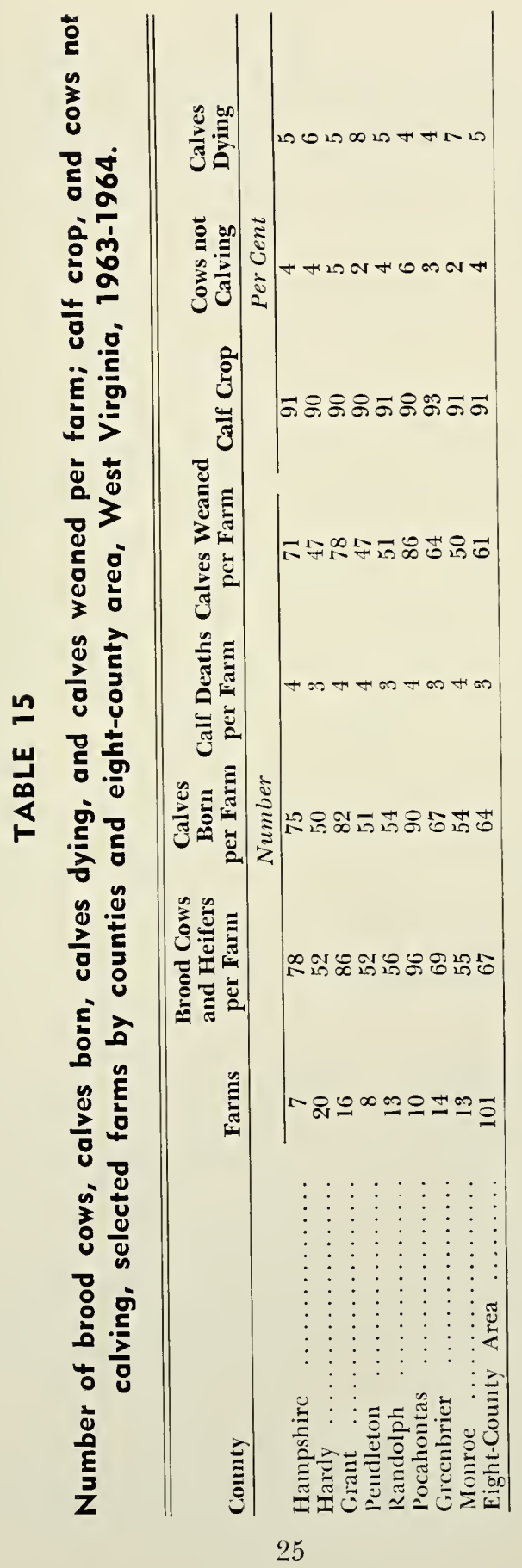




\section{BULLS}

There were nearly three bulls per farm (Table 16). On sample farms, the number of cows per bull ranged from 16 in Pendleton County to 29 in Hardy County. Average for the 101 sample farms was 24 cows per bull, or a little higher than the reported State average of 21 cows per bull. ${ }^{18} \mathrm{~A}$ number of the young bulls were being raised for herd sires and were used for only limited service.

\section{DISPOSITION OF CALVES}

Of the calves born on the sample farms, about 60 per cent were kept and 40 per cent sold in the fall of the year born (Table 17). In Randolph and Pocahontas counties the reverse was true-about 60 per cent were sold in the fall and 40 per cent were kept.

Of the average 35 calves kept, six were for replacements and 29 for future sale. Fifteen of 101 farms sold all their calves except replacements in the fall. Some farmers purchased replacements, as indicated earlier, but many of the farmers who did not keep replacements did not purchase any in the sample year.

\section{OTHER LIVESTOCK}

Although sample selection dictated the major enterprise on the farms to be feeder calf procluction, farmers kept other animals that competed for labor, feed, and shelter. Other forage-consuming livestock such as feeder cattle, ${ }^{19}$ sheep, dairy cows, goats, and horses were converted to animal unit equivalents, on the basis of forage consumption. Animals usually confined, such as swine and poultry, were of less importance on the selected sample farms and were not included in this analysis.

The animal units in the beef cow herd and in other forage-consuming animals are shown in Table 18. Sheep were reported on 65 of the 101 farms. The 65 farms had an average of 98 sheep. Goats were reported only on a few farms and in small numbers. An average of one horse per farm was reported. Dairy cows and their replacements comprised three of the 133 total animal units.

Although farms involved strictly in feeding cattle were excluded from the sample, 85 of the 101 sample farms sold an average of 54 head of feeder cattle, of which 37 head were raised and 17 head purchased (Table 19). During the fall 35 farmers purchased feeder cattle and in

\footnotetext{
"Livestock and Poultry Inventory, S.R.S., Cnited States Department of Agriculture. LiGn 1 (64) 1964 , pp. 14 and 15 .

${ }^{19}$ All calves sold in the fall are referred to as feeder calves. Calves kept and sold at a later date are referred to as feeder cattle even though some may have been sold for immediate slaughter.
} 


\section{TABLE 16}

Number of bulls and total number of cows per bull on selected farms by counties and eight-county area, West Virginia, 1963-1964

\begin{tabular}{|c|c|c|c|c|c|}
\hline County & Farms & $\begin{array}{l}\text { Total } \\
\text { Bulls }\end{array}$ & $\begin{array}{c}\text { Bulls } \\
\text { per Farm }\end{array}$ & $\begin{array}{l}\text { Total } \\
\text { Cows }^{1} \\
\end{array}$ & $\begin{array}{c}\text { Cows } \\
\text { per Bull }\end{array}$ \\
\hline Hampshire .. & 7 & 24 & 3 & 589 & 25 \\
\hline Hardy $\ldots \ldots$ & 20 & 38 & 2 & 1,106 & 29 \\
\hline Grant $\ldots$ & 16 & 56 & 4 & 1,320 & 24 \\
\hline Pendleton & 8 & 28 & 4 & 445 & 16 \\
\hline Randolph & 13 & 36 & 3 & 781 & 22 \\
\hline Pocahontas & 10 & 36 & 4 & 991 & 28 \\
\hline Greenbrier $\quad \ldots \ldots \ldots$ & 14 & 41 & 3 & 987 & 24 \\
\hline Monroe $\quad \ldots \ldots \ldots \ldots$ & 13 & 34 & 3 & 721 & 21 \\
\hline Eight-County Area .. & 101 & 293 & 3 & 6,938 & 24 \\
\hline
\end{tabular}

${ }^{1}$ As some cows were sold between breeding and calving dates, the number of cows exceeds the number of brood cows and heifers used in previous tables.

\section{TABLE 17}

Number and per cent of calves sold and kept per farm on selected farms by counties and eight-county area, West Virginia, 1963-1964

\begin{tabular}{|c|c|c|c|c|}
\hline County & Farms & $\begin{array}{c}\text { Total } \\
\text { Calves }\end{array}$ & $\begin{array}{l}\text { Calves } \\
\text { Sold }\end{array}$ & $\begin{array}{l}\text { Calves } \\
\text { Kept }\end{array}$ \\
\hline & \multicolumn{2}{|c|}{ Number } & \multicolumn{2}{|c|}{ Per Cent } \\
\hline Hampshire & 7 & 71 & 42 & 58 \\
\hline Hardy $\ldots .$. & 20 & 47 & 28 & 72 \\
\hline Grant & 16 & 78 & 16 & 84 \\
\hline Pendleton & 8 & 47 & 49 & 51 \\
\hline Randolph & 13 & 51 & 66 & 34 \\
\hline Pocahontas & 10 & 86 & 60 & 40 \\
\hline Greenbrier & 14 & 64 & 42 & 58 \\
\hline Monroe $\quad \ldots \ldots \ldots$ & 13 & 50 & 50 & 50 \\
\hline Eight-County Area & 101 & 61 & 43 & 57 \\
\hline
\end{tabular}

the spring nine farmers made purchases. Some farmers made both spring and fall purchases.

Seventy-nine per cent of the feeler cattle sold were in two weight classes-500 to 799 pounds, and 950 pounds and up. The first group (which were wintered light for subsequent grazing) accounted for 41 per cent and the latter group 38 per cent of the sales. The practice of heavier feeding was concentrated in the northern counties of Hampshire, Hardy, Grant, and Pendleton where a larger per cent of the cropland was bottom land and larger acreages of grains were grown. 


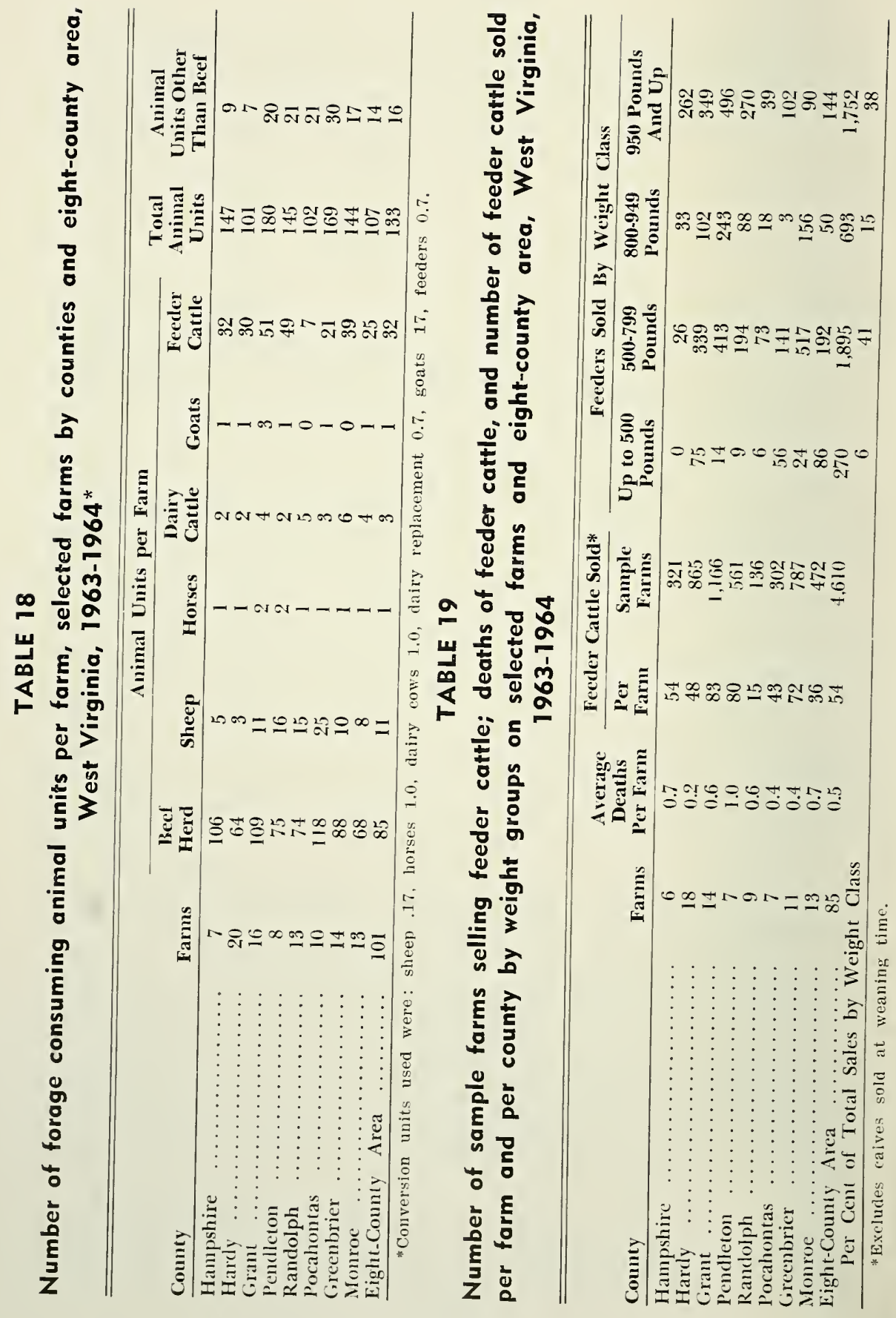




\section{Land Required Per Animal Unit on Farms}

Tables 20 through 23 combine the land resources and forage-consuming animal resources to determine the acreage of land used per animal unit, the average being 4.2 acres. The range was from 3.3 acres in Greenbrier County to 4.8 acres in Pendleton County and 4.7 acres in Pocahontas County (Table 20). Most of the difference in land per animal unit among counties was due to differences in the amount of upland pasture.

Acres of cropland per animal unit ranged from 0.73 in Grant County to $1.3 \mathrm{I}$ in Hampshire County (Table 2I). The cropland per animal unit for the average sample farm was 0.93 acre, of which 0.51 acre was upland and 0.42 acre was bottom land.

The 101 farms in the study had an average of 0.22 acre of corn, 0.11 acre of small grain, and 0.58 acre of hay per animal unit (Table 22). Corn acreage grown per animal unit ranged from 0.08 in Randolph County to .43 in Hardy County. Acres of small grains per animal unit ranged from 0.04 acre in Randolph County to 0.19 acre in Hardy County. The number of acres of hay per animal unit was largest in Randolph County, one acre, and smallest in Greenbrier County, 0.38 acre.

Pasture land per animal unit for the study area averaged 3.2 acres, and ranged from 2.5 in Greenbrier County to 3.9 in Pendleton County (Table 23). In addition, 82 of the 101 farmers grazed their meadows for an average of 47 days in the fall of 1963, and 42 farmers grazed their corn fields after picking or cutting the corn.

\section{The Average Farm: Its Resources, Production, and Income}

A farm having characteristics which are average for farms included in the study might be used as a guide for evaluating the present status of a given farm. Although the sample of farms was not random, it is thought to be representative of successful beef cow-calf farms in the area.

As previously described, the average land resource included 555 acres of which 124 acres were cropland and $43 \mathrm{I}$ acres were pasture land. Of this land, $46 \mathrm{I}$ acres were upland and 94 acres were bottom land.

The livestock herd included 133 animal units of forage-consuming livestock, the majority of which were beef cattle. If a beef cow herd alone had been kept, sufficient forage would have been available for 


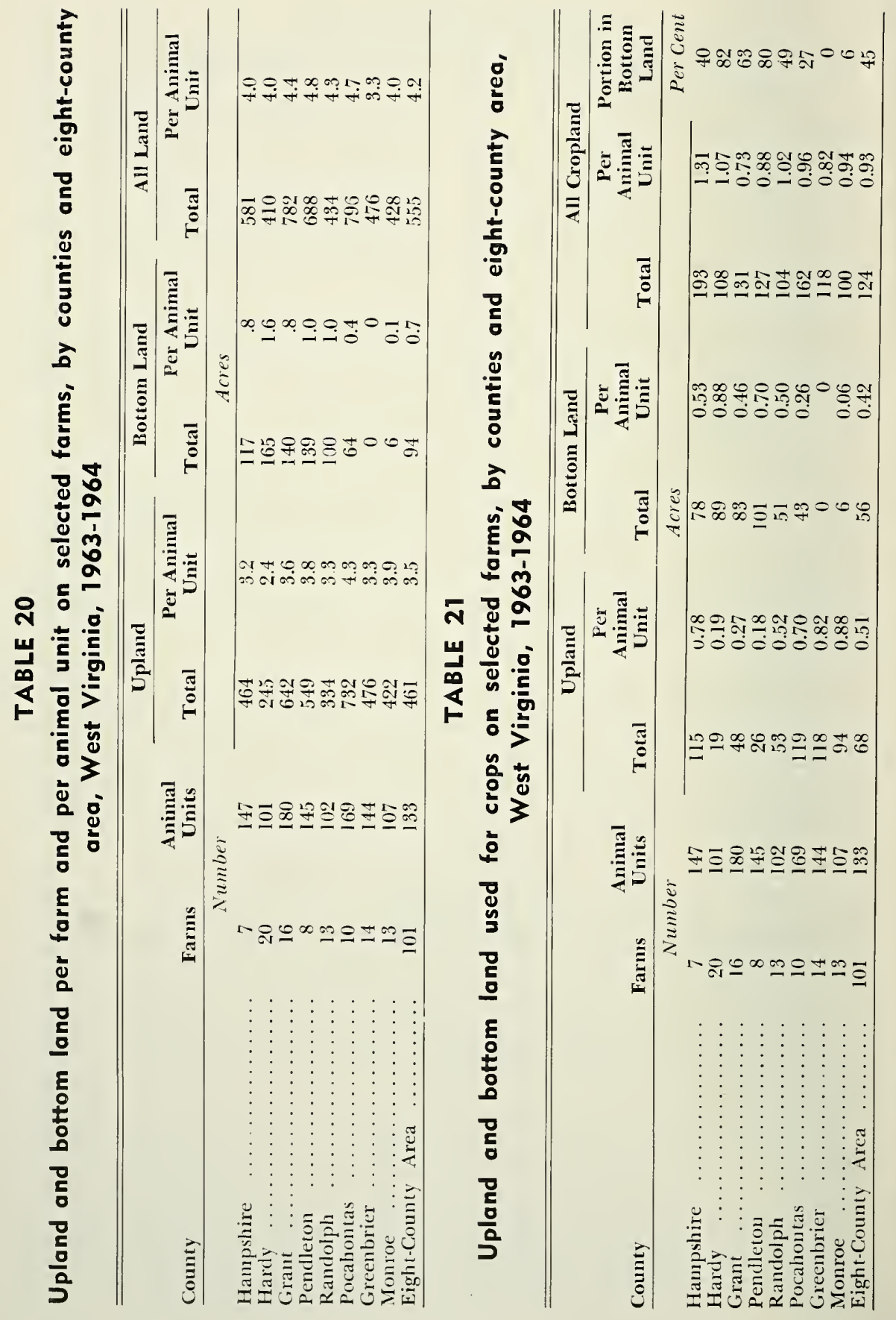


109 beef cows plus replacements and bulls. Costs for such an organization would probably not differ significantly from the existing costs per cow as forage production and machinery used would not be materially changed.

In the following sections, gross returns, investment, and costs for a 109 cow herd are presented, and returns to labor and investment are estimated.

\section{GROSS RETURNS}

Gross returns on beef cattle farms are influenced by the weight and price of calves. Weights and prices used in the analysis were based on calves sold at the State Demonstrational Sales for 1955 through 1964 (Table 24). During that ten-year period steers averaged 430 pounds, and sold for $\$ 25.84$ per hundredweight or about $\$ 111$ per steer. Heifers averaged 406 pounds, and sold for $\$ 21.08$ per hundredweight, or about $\$ 86$ per heifer.

On the sample farms, the calf crop was 91 per cent. Assuming that steer and heifer calves were equal in number, an average of 45.5 steers and 45.5 heifers would reach weaning weight per 100 cows each year. On the basis of this distribution and the average weight and market price at State Demonstrational Sales, the value of steer calves sold from a 100 cow herd was $\$ 5,065$ (Table 25 ).

In these same herds an average of 16 heifers per 100 cows was kept for replacement and 29.5 heifer calves sold. Of the 16 replacements kept, three were sold before calving and 13 entered the cow herd. The average annual sales per 100 cow herd was $\$ 2,530$ from heifers sold at weaning and $\$ 300$ for heifers sold at a later time.

If 13 heifers enter a 100 cow herd each year and the size of the herd remains constant, then 13 cows are removed. With a 2 per cent death loss, 11 cows will be available for sale. The average annual income from the sale of cull cows from a 100 cow herd is $\$ 1,650$.

The sum of all sales from a 100 cow herd was estimated at $\$ 9,545$ or $\$ 95.45$ per cow in the herd.

\section{INVESTMENT}

Investments included in the analysis were those items specifically concerned with beef cattle production including the beef herd, Iand, buildings, and machinery. These investments are summarized in Table 26.

\section{The Beef Herd}

The composition of herds necessary to maintain a constant size was 1.18 animal units of females and 0.04 animal units of males or a 


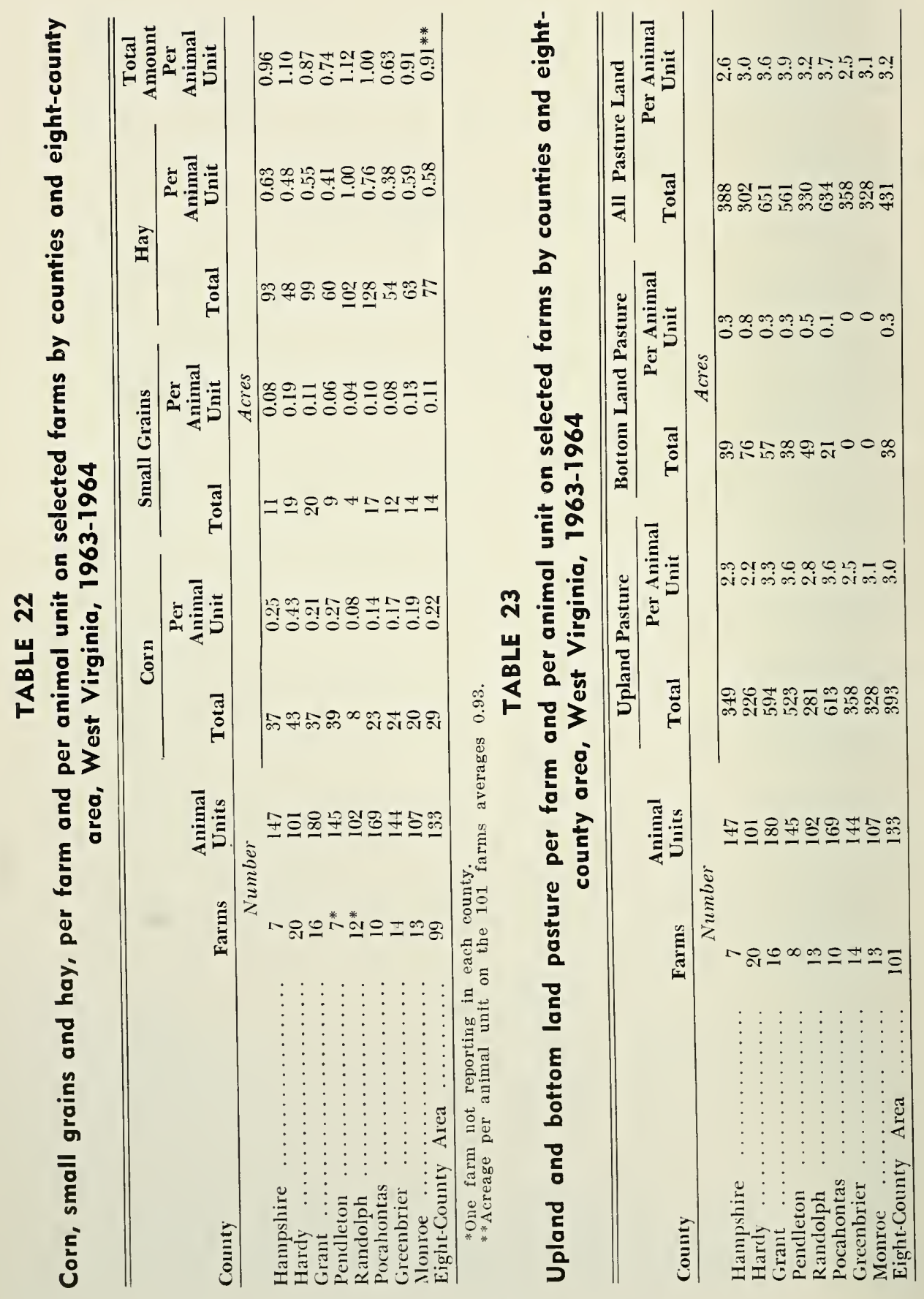


total of 1.22 animal units per mature cow (Table 27). Two conversions were used in preparing budgets. One was the cow replacement unit (CRU) of 1.18 that included all females. The other was the animal units per cow of 1.22 that included all animals. These conversions provide for a self-perpetuating herd of constant size, with cows averaging nine productive years and a 91 per cent calf crop.

Cows and Heifers: Investment in the female stock was $\$ 236$ per cow replacement unit. This represents an average investment of $\$ 200$ per animal unit.

Bulls: Bull investment was based on a mature bull cost of $\$ 500$, a sale of the bull weighing 1,600 pounds at $\$ 16$ per hundred or $\$ 256$, and an average investment of $\$ 378(\$ 500+\$ 256 \div 2)$. Since herds averaged 24 cows per bull, the average value per cow replacement unit was $\$ 16$ $(\$ 378 \div 24$ cows $)$.

\section{Cropland}

\section{LAND}

The average number of acres of cropland per cow replacement unit, 1.14, was determined by dividing the 124 acres of cropland per farm by the 109 cow replacement units per farm. With cropland valued at $\$ 250$ per acre, the cropland investment per cow replacement unit was $\$ 285$ ( $\$ 250 \times 1.14$ acres), Table 26 .

\section{Pasture Land}

The pasture land per cow replacement unit was 3.95 acres (431 acres per farm divided by 109 cow replacement units per farm). With pasture land valued at $\$ 80$ per acre, the investment per cow replacement unit was $\$ 316$ ( $\$ 80 \times 3.95$ acres).

\section{BUILDINGS AND SILOS}

The value of real estate in West Virginia in 1963 was estimated at $\$ 82$ per acre. $^{20}$ For this analysis, building values on West Virginia beef-cattle farms were estimated at 10 per cent of the real-estate value or $\$ 8.20$ per acre. Total land per cow replacement unit was 5.09 acres (1.14 acres cropland plus 3.95 acres pasture); thus building investment was estimated at $\$ 42$ per cow $(5.09 \times \$ 8.20)$.

Investment in silos was estimated at $\$ 18$ per cow replacement unit. This was based on a construction cost of $\$ 15$ per ton, ${ }^{21}$ an average lifetime investment of $\$ 7.50$ per ton, and 2.36 tons of silage capacity per cow replacement unit.

${ }^{20}$ Farm Real Estate Market Developments, E.R.S., USDA, CD-66, October 1964, p. 13. ${ }^{2}$ Richard T. Dailey, Agricultural Planning Data for the Northeastem United States, AE \& RS 51, July 1965, Pennsylvania State University, p. 61. 


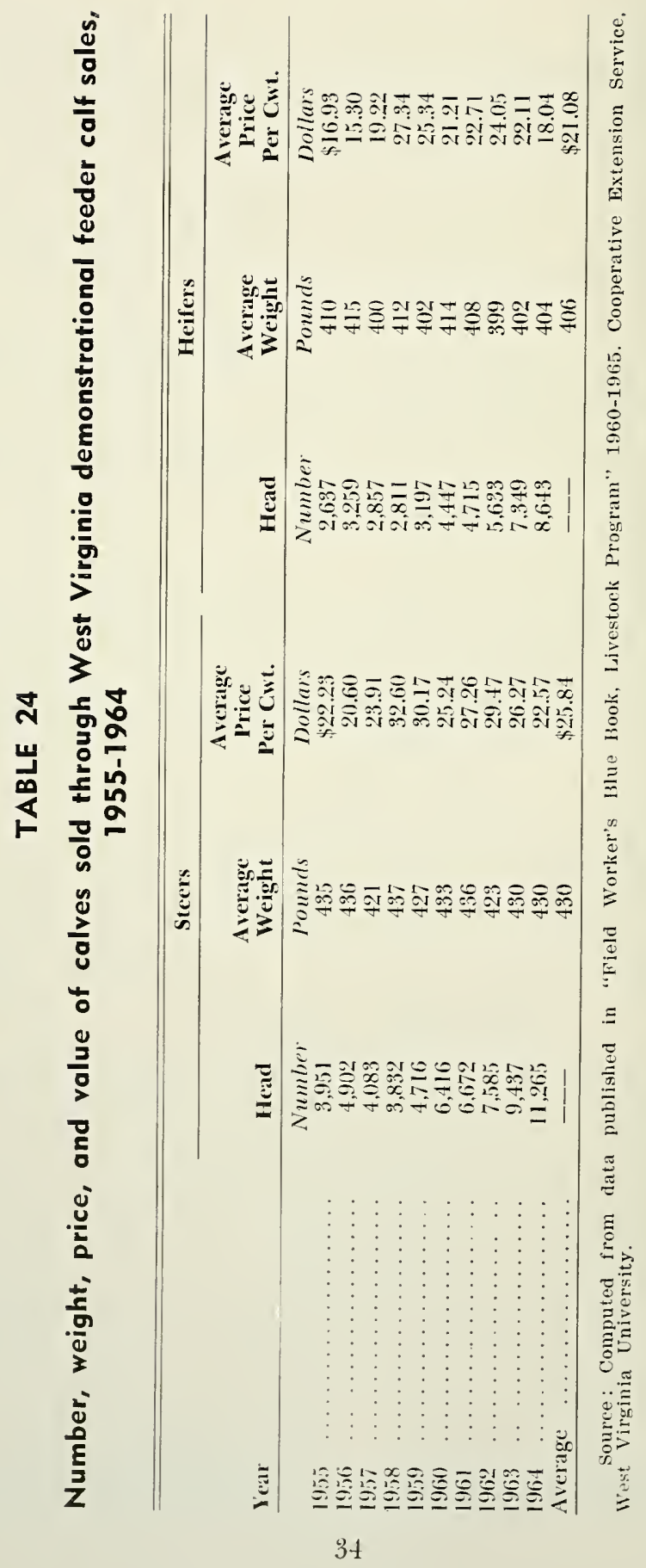


TABLE 25

Estimated income per 100 cow herd for selected farms in an eight-county orea, West Virginio, 1963

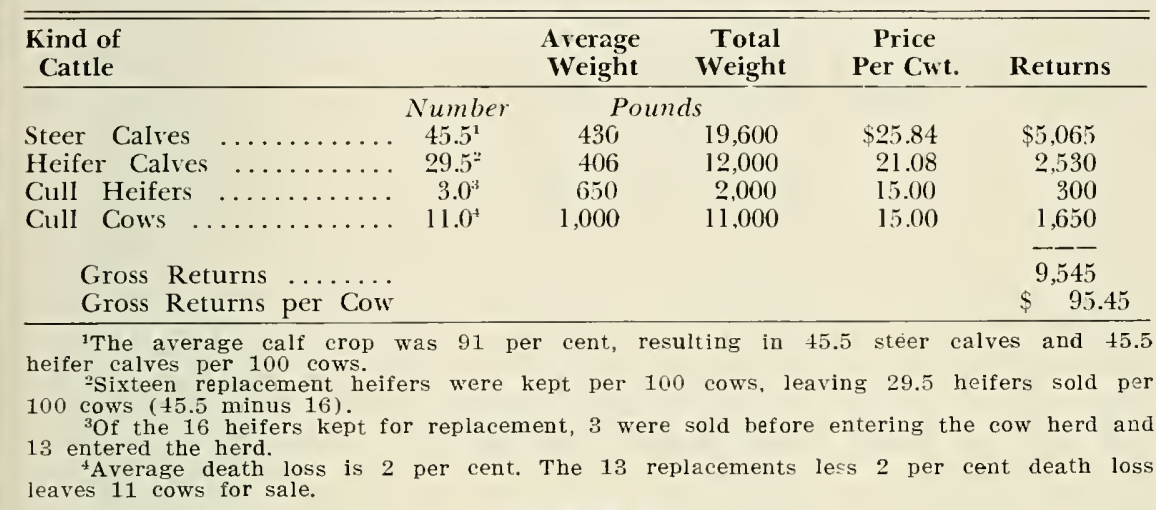

TABLE 26

Estimated investment per cow replacement unit for selected farms in an eight-county area, West Virginia, 1963-1964

\begin{tabular}{|c|c|c|c|}
\hline Resource & Amount & Price & $\begin{array}{c}\text { Investment } \\
\text { per Cow } \\
\text { Replacement Unit }\end{array}$ \\
\hline Cows and Heifers ...... & 1.18 Animal Units & $\$ 200$ & $\$ 236$ \\
\hline Bulls $\ldots \ldots \ldots \ldots \ldots \ldots$ & .042 per Cow & 378 & 16 \\
\hline Cropland $\ldots \ldots \ldots \ldots \ldots$ & 1.14 Acres & 250 & 285 \\
\hline Pasture. & 3.95 Acres & 80 & 316 \\
\hline Buildings .. & 5.09 Acres" & 8.20 & 42 \\
\hline Silo $\quad \ldots \ldots \ldots \ldots \ldots \ldots$ & 2.36 Tons & 7.50 & 18 \\
\hline Machinery......... & & & 96 \\
\hline Total Investment ... & & & $\$ 1,009$ \\
\hline
\end{tabular}

${ }^{1}$ Assumes an average herd size of 109 cow replacement units.

"Building investment is estimated at 10 per cent of the average $(\$ 82.00)$ per acre value of West Virginia real estate.

\section{MACHINERY}

Machinery investment varies with the size of herd because of changes in the kind and size of equipment. For a herd of 100 beef cows the machinery investment was estimated to be $\$ 10,010$ (Table 28). In order to estimate investments and costs for herds in excess of 100 cows, and since the costs are not doubled when herd size doubles, estimates were also developed for a 200 cow herd. For the latter the estimated investment was $\$ 14,473$ (Table 29), an increase of $\$ 4,463$ (\$14,473$\$ 10,010)$, or $\$ 44.63$ per cow.

On the average farm stocked with 109 cows, the investment in machinery then would be $\$ 10,412$ ( $\$ 10,010$ for 100 cows plus $\$ 44.63$ $\mathrm{x} 9$ ), or $\$ 96$ investment in machinery per cow. 


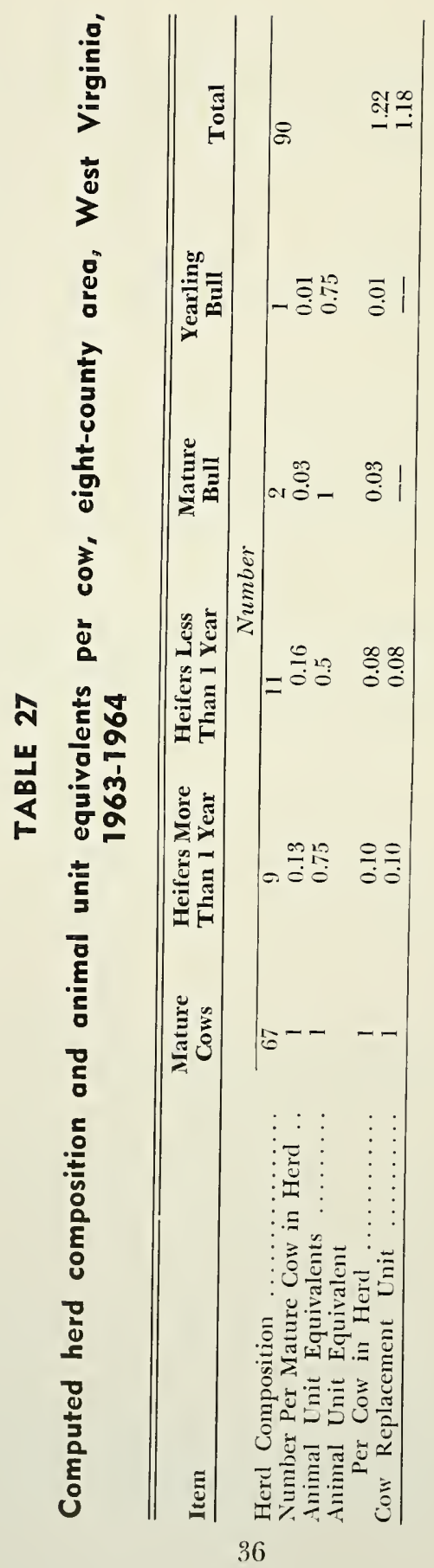


TABLE 28

Machinery investment, average investment, and annual depreciation for a 100 cow herd $^{1}$

\begin{tabular}{|c|c|c|c|c|}
\hline Machine & Cost & $\begin{array}{c}\text { Average } \\
\text { Investment }\end{array}$ & $\begin{array}{l}\text { Estimated } \\
\text { Years Life }\end{array}$ & $\begin{array}{c}\text { Annual } \\
\text { Depreciation }\end{array}$ \\
\hline 2 Tractors. & $\$ 6,400$ & $\$ 3,200$ & 15 & $\$ 427$ \\
\hline Plow $\left(2-14^{\prime \prime}\right) \ldots$ & 300 & 150 & 15 & 20 \\
\hline Disc $\left(8^{\prime}\right.$ tandem) & 330 & 165 & 15 & 22 \\
\hline Grain Drill ............ & 650 & 325 & 20 & 32 \\
\hline Sprayer $\quad \ldots \ldots \ldots \ldots \ldots$ & 200 & 100 & 10 & 20 \\
\hline Mower $\quad \ldots \ldots \ldots \ldots \ldots \ldots$ & 540 & 270 & 12 & 45 \\
\hline$\ldots \ldots \ldots \ldots \ldots \ldots$ & 560 & 280 & 12 & 47 \\
\hline Baler $\ldots .$. & 2,300 & 1,150 & 10 & 230 \\
\hline 2 Wagons ........... & 500 & 250 & 15 & 33 \\
\hline Manure Spreader ......... & 600 & 300 & 15 & 40 \\
\hline Manure Loader ......... & 300 & 150 & 10 & 30 \\
\hline Elevator $\ldots \ldots \ldots \ldots \ldots$ & 400 & 200 & 15 & 27 \\
\hline Field Chopper $\ldots \ldots \ldots \ldots$ & 2,000 & 1,000 & 10 & 200 \\
\hline Forage Blower $\ldots \ldots \ldots$ & 950 & 475 & 12 & 79 \\
\hline Self-unloading Wagon .... & 950 & 475 & 15 & 63 \\
\hline Corn Planter (2 rows) .... & 330 & 165 & 20 & 16 \\
\hline Cultivator $\ldots \ldots \ldots \ldots$ & 310 & 155 & 12 & 26 \\
\hline Truck $(3 / 4$ Ton $) \ldots \ldots \ldots$ & 2,400 & 1,200 & 8 & 300 \\
\hline Total & $\$ 20,020$ & $\$ 10,010$ & & $\$ 1,657$ \\
\hline
\end{tabular}

${ }^{1}$ Barr, A. L. Beef Cattle Production Costs and Returns for the Cow-Calf System in West Virginia, p. 24.

\section{Costs}

Charges were placed on the major items of cost associated with beef production. These costs were determined by using the assumption that production costs were the same as if all livestock on the sample farms had been beef cattle with herds composed of 109 cows, their replacements, and the bulls. A summary of the specified items is presented in Table 30. The annual cost per cow replacement unit, excluding family labor and interest on investment, is estimated at $\$ 74.00$.

\section{Forage}

On the sample farms the average annual production included 160 tons of hay and 204 tons of silage. Assuming three tons of silage equivalent to one ton of hay, the annual production was equivalent to 228 tons of hay. An average of six tons of hay was purchased and 15 tons was sold or not fed. This resulted in an average annual feeding of 219 tons of forage to the herds with a composition of 133 animal units, including 109 cows. The rate of feeding hay was 1.65 tons per animal unit or 2.0 tons per cow replacement unit. 
TABLE 29

Machinery investment, average investment, and annual depreciation for a 200 cow herd

\begin{tabular}{|c|c|c|c|c|}
\hline Machine & Cost & $\begin{array}{c}\text { Average } \\
\text { lnvestment }\end{array}$ & $\begin{array}{c}\text { Estimated } \\
\text { Year of } \\
\text { Life }^{1}\end{array}$ & $\begin{array}{c}\text { Annual } \\
\text { Depreciation }\end{array}$ \\
\hline 3 Tractors, 2 sizes $\ldots \ldots \ldots$ & $\$ 10,000$ & $\$ 5,000$ & 15 & $\$ 667$ \\
\hline 2 Plows, (2-14" and 3-14") .. & 800 & 400 & 15 & 533 \\
\hline Disc $\left(10^{\prime}\right.$ tandem $) \ldots \ldots \ldots$ & 665 & 333 & 15 & 44 \\
\hline Grain Drill $\ldots \ldots \ldots \ldots \ldots$ & 650 & 325 & 20 & 32 \\
\hline Sprayer $\quad \ldots \ldots \ldots \ldots \ldots$ & 200 & 100 & 10 & 20 \\
\hline 2 Mowers ............. & 1,080 & 540 & 12 & 90 \\
\hline Rake $\quad \ldots \ldots \ldots \ldots \ldots \ldots$ & 560 & 280 & 12 & 47 \\
\hline$\ldots \ldots \ldots \ldots \ldots \ldots$ & 2,300 & 1,150 & 10 & 230 \\
\hline 3 TVagons ........... & 750 & 375 & 15 & 50 \\
\hline 2 Manure Spreaclers ....... & 1,200 & 600 & 15 & 80 \\
\hline Manure Loader .......... & 300 & 150 & 10 & 30 \\
\hline 2 Elevators . . . . . . . . & 800 & 400 & 15 & 53 \\
\hline Field Chopper .......... & 2,000 & 1,000 & 10 & 200 \\
\hline Forage Blower $\ldots \ldots \ldots \ldots$ & 950 & 475 & 12 & 79 \\
\hline Self-unloading Wagon .... & 950 & 475 & 15 & 63 \\
\hline Corn Planter ............. & 330 & 165 & 20 & 17 \\
\hline Cultivator $\ldots$. & 310 & 155 & 12 & 26 \\
\hline Truck (Pickup) & 2,000 & 1,000 & 8 & 250 \\
\hline \multirow[t]{2}{*}{ Truck (Large) ........... } & 3,100 & 1,550 & 8 & 388 \\
\hline & $\$ 28,945$ & $\$ 14,473$ & & $\$ 2,899$ \\
\hline
\end{tabular}

'Source: Agricultural Engineer's Yearbook, 1962 and 1964.

Hay was valued at $\$ 15.00$ a ton. This value is the estimated variable cost of production of hay on West Virginia farms..2

On the basis of the above values, the forage cost per cow and replacement was $\$ 30$.

\section{Pasture}

The sample farms used an average of 431 acres of pasture. This was 3.24 acres per animal unit or 3.95 acres per cow replacement unit.

A charge of $\$ 1.00$ per acre was placed on pasture to meet the average annual cash cost. On the sample farms, 49 per cent of the pasture acreage was improved by liming and fertilizing. At a cost of $\$ 20$ per acre, a treatment of half the pasture land each five years, and a 50 per cent cost-sharing arrangement with the government, the average annual casli cost would be $\$ 1.00$ per acre or $\$ 3.95$ per cow replacement unit.

\section{Concentrates}

Thirty-seven of the 101 farmers fed no concentrates to any of their beef breeding herd in the winter of 1963-64. On those farms on which concentrates were fed, 17 fed bulls only, 11 fed heifers only, eight fed

${ }^{22}$ See Barr, A. L., West Virginia Agricultural Exp. Station Bull. 527, for costs of production. 
TABLE 30

Estimated costs per cow replacement unit for selected farms with 109 cows in an eight-county area, West Virginia, 1963-1964

\begin{tabular}{|c|c|c|c|c|}
\hline Item & Unit & Quantity & Price & Cost \\
\hline Forage in Hay Equivalents. & Ton & 2.00 & $\$ 15.00$ & $\$ 30.00$ \\
\hline Pasture $\ldots \ldots \ldots \ldots \ldots$ & Acres & 3.95 & 1.00 & 3.95 \\
\hline Grain $\quad \ldots \ldots \ldots \ldots \ldots \ldots$ & Cwt. & 1.00 & 2.43 & 2.43 \\
\hline Protein Supplement ...... & Cwt. & 0.13 & 4.74 & .62 \\
\hline Salt $\ldots \ldots \ldots \ldots \ldots \ldots$ & Lb. & 30.50 & .03 & .92 \\
\hline Health Costs & & & & 2.00 \\
\hline Marketing . . & Lb. & 446.00 & .75 & 3.45 \\
\hline Bull Cost & & & & 2.54 \\
\hline Fence $\quad \ldots \ldots \ldots \ldots \ldots \ldots$ & & & & 2.40 \\
\hline Machinery Depreciation ... & & & & 16.23 \\
\hline Building Depreciation .... & & & & 2.10 \\
\hline Building Maintenance .... & & & & .42 \\
\hline Insurance on Machinery ... & $\$ 100$ & $\$ 96$ & .49 & .47 \\
\hline Insurance on Building ..... & 100. & 42 & .49 & .21 \\
\hline Insurance on Cattle ....... & 100. & 252 & .275 & .69 \\
\hline Taxes on Land .......... & 100. & $300^{*}$ & .92 & 2.76 \\
\hline Taxes on Building ........ & 100. & $21 *$ & .92 & .19 \\
\hline Taxes on Machinery ...... & 100. & $48^{*}$ & .46 & .22 \\
\hline Taxes on Cattle .......... & 100. & $126 *$ & .46 & .58 \\
\hline \multicolumn{4}{|c|}{ Silo Depreciation, Insurance and Taxes } & 1.82 \\
\hline \multicolumn{4}{|c|}{ Total Costs per Cow Replacement Unit } & $\$ 74.00$ \\
\hline
\end{tabular}

*Assessed value of 50 per cent of average value.

heifers and bulls only, and six fed cows and heifers. The remaining 22 farmers fed concentrates to all beef animals. Thus, 28 per cent of the cow herds, 47 per cent of the heifers and 47 per cent of the bulls were fed concentrates.

In those herds where concentrates were fed, the rate of feeding was 385 pounds per cow, 421 pounds per bred heifer, 470 pounds per heifer less than one year old, and 1,013 per bull. Since all farmers did not feed concentrates, averages are lower when the quantities are allocated to the 101 farms. For the 101 farms, the rate of feeding concentrates was 72 pounds per cow, 103 pounds per bred heifer, 72 pounds per heifer under one year, and 408 pounds per bull, or an average of 113 pounds per cow replacement unit. This concentrate included approximately 100 pounds of grain and 13 pounds of protein supplement.

The average price received for corn by West Virginia farmers for the years 1959 through 1963 was $\$ 1.36$ per bushel, or $\$ 2.43$ per hundred pounds. ${ }^{23}$ The price paid for soybean oil meal during this same period was $\$ 4.74$ per 100 pounds. Thus the value of grain fed per cow replacement unit was $\$ 2.43$ and the value of protein supplement was $\$ 0.62$ per cow in the herd.

${ }^{23} 1964$ West Virginia Agricultural statistics, pp. 42 and 45 . 


\section{Salt}

The quantity of mineralized salt required was estimated at 25 pounds per cow, or 30.5 pounds per cow replacement unit. At $\$ 3.00$ per 100 pounds, the salt costs averaged $\$ 0.92$ per cow replacement unit.

\section{Health Costs}

Veterinary fees and other costs associated with the maintenance and improvement of health were estimated at $\$ 2.00$ per cow replacement unit.

\section{Marketing Costs}

Transportation, sales fees, and other costs involved in marketing cattle were charged at $\$ 0.75$ per 100 pounds of live weight.

\section{Bull Cost}

Bull costs were estimated on the assumption that the bulls were purchased at a price of $\$ 500$. With a resale of a 1,600 pound bull at $\$ 16$ per hundred weight, depreciation in value of $\$ 244$, and four years of service, the annual depreciation is $\$ 61$ per bull. In these herds the farmers averaged 24 cows per bull. Thus the annual bull depreciation cost was $\$ 2.54$ per cow.

\section{Fence}

The average annual charge for fence was $\$ 2.40$ per cow replacement unit on the basis of a 100 cow herd. ${ }^{2 t}$

\section{Machinery Depreciation and Repairs}

The estimated annual depreciation for the machinery required was $\$ 1,657$ for a 100 cow herd and $\$ 2,899$ for the 200 cow herd (Tables 28 and 29). If machinery costs for herds between these sizes vary in proportion to the change, then the machinery depreciation for the 109 cow herds would be $\$ 1,769$. This represents an average cost of $\$ 16.23$ per cow replacement unit.

The operating costs for farm machinery, including repairs, fuel, and lubricants, were included with the cost of hay. Since these are variable costs, they change in clirect proportion with the change in quantity of forage, and hence with the number of cows.

${ }^{24}$ A. L. Harr, Beef Catle Proluction costs and returns for the Cono-Calf System in West Virginia, West Virginia Agricultural Experiment Station Bulletin 527. 


\section{Building Depreciation and Repair}

The building investment per cow replacement unit was estimated at $\$ 42$ (see Table 26) with investment representing 50 per cent of the cost. The first cost of building would have been $\$ 84$ per cow replacement unit. With a 40 year life for buildings, the annual depreciation would be $\$ 2.10$.

Building repair costs were based on an annual repair rate of one per cent of the average building value. This provides an annual repair charge of 42 cents per cow replacement unit.

\section{Insurance}

The cost of insurance was estimated to be $\$ 0.49$ per $\$ 100$ value for buildings and machinery and $\$ 0.275$ per $\$ 100$ value of cattle. ${ }^{2-i}$ With an average machinery investment per cow replacement unit of $\$ 96$ the insurance cost was $\$ 0.47$. The building investment averaged $\$ 42$ with an insurance charge of $\$ 0.21$ per cow replacement unit. Cattle investment was $\$ 252$ with an insurance cost of $\$ 0.69$.

\section{Taxes}

The tax rate used was an average for the rural area of the eightcounty area for 1963 and was a rate of 92 cents per $\$ 100$ assessed value for farm real estate, including land and buildings. The rate was 46 cents for farm machinery and livestock. ${ }^{26}$

Taxes were calculated on a tax assessment value which is 50 per cent of "true and actual value." As a result, the base for taxes was 50 per cent of the value for insurance. Cropland value was $\$ 285$ and pasture value was $\$ 316$ per cow replacement unit (Table 26) or a total market value of $\$ 601$ and an assessed value of $\$ 300$ per cow replacement unit. With a tax rate of 92 cents the land tax was $\$ 2.76$ per cow replacement unit.

The assessed value on buildings was \$21 per cow replacement unit; thus the annual tax for buildings was 19 cents per replacement unit. The assessed value of machinery and cattle was $\$ 48$ and $\$ 126$ respectively; thus, the tax was 22 cents on machinery and 58 cents on cattle per cow replacement unit.

\section{Silo}

Silage capacity per cow replacement unit was 2.36 tons (Table 26). With storage costs determined on the basis of an upright silo, the initial

\footnotetext{
${ }^{25}$ Rates based on a policy held hy one author of this publication for insurance on a beef cattle farm in West Virginia.

${ }^{20}$ Thirtieth Biennial Report of the Tax Commission of West Virginia, pp. 74, 80, 92, $104,246,284,295,334$.
} 
silo cost was $\$ 15$ per ton of capacity. ${ }^{2 i}$ This is an initial investment of $\$ 35.40$ per cow replacement unit $(2.36 \times \$ 15)$. With a 25 year life, the annual depreciation is $\$ 1.42(\$ 35.40 \div 25)$. The annual insurance charge based on an average lifetime value of $\$ 17.70$ and a rate of $\$ 0.49$ per $\$ 100$ investment is about nine cents. The assessment value for tax purposes is $\$ 8.85$ and the rate is $\$ 0.92$, which results in an annual cost of 31 cents per cow replacement unit.

\section{Returns to Labor and Investment}

Income per cow replacement unit in the average 109 cow herd was estimated to be $\$ 95.45$ (Table 25) and costs were estimated to be $\$ 74$ (Table 30). Thus, the return to labor and investment per cow was $\$ 21.45$ with investment estimated at $\$ 1,009$ per cow replacement unit (see Table 26). The return on investment was 2.12 per cent with no charge made for labor.

On the 101 study farms, the return to labor and investment from the 67 cow herd was estimated to be $\$ 1,437$. If all forage resources were devoted to beef production and herd size were increased to a 109 cow herd, return to labor and investment would be $\$ 2,338$.

From the previous estimates, it is obvious that further size adjustments will be necessary for feeder calf producers to obtain a satisfactory return to labor and investment. With the present productivity levels of the 101 sample farms, a return to investment and labor of $\$ 3,000$ would require a herd of 135 cows, an investment of $\$ 134,865$, and would yield a return of 2.23 per cent on investment. Estimates of costs per cow replacement unit in a 135 cow herd are presented in Table 31.

Capital requirements for the beef cow-calf enterprise are high and the rate of return on investment is relatively low. If a farmer owns the capital without debts, however, he may perfer this system of farming to those with higher and more exacting labor requirements.

Although capital invested in beef-cattle production yielcls a lower return than that typically returned by safe off-farm investments, such as savings accounts or bonds, the increase in the market prices of farm real estate have exceeded the rate of return which could have been obtained in the capital market. Market prices of farm real estate in West Virginia increased by 97 per cent between the 1951-53 period and the 1961-63 period. ${ }^{28}$ Thus a return in the form of capital gains on the land is also an important consideration.

${ }^{27}$ Alfindluml Pliming Date for the Northeastern Uniled Stales. p. 61.

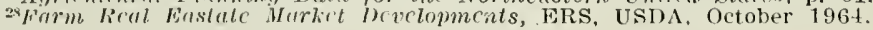


TABLE 31

Estimated costs and returns per cow replacement unit for selected farms with 135 cows in an eight-county area, West Virginia

\begin{tabular}{|c|c|c|c|c|}
\hline Item & Unit & Quantity & Price & Cost \\
\hline Forage in Hay Equivalents. & Ton & 2.00 & $\$ 15.00$ & $\$ 30.00$ \\
\hline Pasture $\ldots \ldots \ldots \ldots \ldots \ldots$ & Acre & 3.95 & 1.00 & 3.95 \\
\hline Grain $\ldots \ldots \ldots \ldots \ldots \ldots$ & Cwt. & 1.00 & 2.43 & 2.43 \\
\hline Protein Supplement ....... & Cwt. & 0.13 & 4.74 . & .62 \\
\hline Salt $\ldots \ldots \ldots \ldots \ldots \ldots \ldots$ & Lb. & 30.50 & .03 & .92 \\
\hline Health Costs & & & & 2.00 \\
\hline Marketing .. & Lb. & 446.00 & .75 & 3.45 \\
\hline Bull Cost ... & & & & 2.54 \\
\hline Fence $\quad \ldots \ldots \ldots \ldots \ldots \ldots$ & & & & 2.40 \\
\hline Machinery Depreciation. . & & & & 15.49 \\
\hline Building Depreciation $\ldots \ldots$ & & & & 2.10 \\
\hline Building Maintenance .. & & & & .42 \\
\hline Insurance on Machinery ... & $\$ 100$ & $\$ 86$ & .49 & .42 \\
\hline Insurance on Buildings .... & 100. & 42 & 49 & 21 \\
\hline Insurance on Cattle $\ldots \ldots$ & 100. & 252 & .275 & .69 \\
\hline Taxes on Land .......... & 100. & $300^{*}$ & .92 & 2.76 \\
\hline Taxes on Building .. & 100. & $21^{*}$ & 92 & .19 \\
\hline Taxes on Machinery & $\mathrm{I}(00$. & $43^{*}$ & .46 & .20 \\
\hline Taxes on Cattle ......... & 100. & $126^{*}$ & .46 & .58 \\
\hline Silo Depreciation, Insurance & 1 Tax & & & 1.82 \\
\hline \multirow{5}{*}{\multicolumn{4}{|c|}{$\begin{array}{l}\text { Total Costs per Cow Replacement Unit } \ldots \ldots \ldots \ldots \ldots \ldots \\
\text { Return to Labor and Investment per Cow } \ldots \ldots \ldots \ldots \ldots \\
\text { Returns to Labor and Investment from } 135 \text { Cows } \ldots \ldots \ldots \ldots \\
\text { Investment Required for } 135 \text { Cows } \ldots \ldots \ldots \ldots \ldots \ldots \ldots\end{array}$}} & $\$ 73.19$ \\
\hline & & & & 2226 \\
\hline & & & & 3005.10 \\
\hline & & & & $\$ 134.865$ \\
\hline & & & & $2.23 \%$ \\
\hline
\end{tabular}

*Assessed value of 50 per cent of average value.

**No charge is deducted for labor. 


\section{BIBLIOGRAPHY}

Agricultural Planning Data for the Northeastern United States. A. E. and R. S. 51, July 1965, Agricultural Experiment Station, Pennsylvania State University, University Park, 1965.

Barr; A. L. Beef Cattle Production Costs and Returns for the Cow-Calf System in West Virginia. Bulletin 527, Agricultural Experiment Station, West Virginia University, Morgantown, June 1966.

Climate and Man. United States Department of Agriculture, 1941 Yearbook of Agriculture, Washington: Government Printing Office, 1941.

Climatological Data Jest Virginia. Department of Commerce, Annual Summaries 1961, 1962, 1963, 1964, and 1965, Washington: Government Printing Office.

Farm Real Estate Market Developments. United States Department of Agriculturc, CD-61, Washington: Economic Research Service, 1964.

Field Workers' Blue Book, Livestock Program. 1960-1965, "Summary of West Virginia Demonstrational Feeder Calf Sales," Cooperative Extension Service, West Virginia University, Morgantown.

Handbook of Agricultural Charts 1965. United States Department of Agriculture, Agriculture Handbook No. 300, Washington: Govermment Printing Office, 1965.

Jung, G. A., Pertinent Facts Concerning Alfalfa Variety-Fall Management Study. Unpublished data, West Virginia University, Morgantown, 1963.

Land Resource Map of West Virginia. United States Department of Agriculture. Soil Conservation Service, Beltsville, Md. 1958.

Land Resource Regions and Major Land Resource Areas of The United States. United States Department of Agriculture, Soil Conservation Service, Agriculture Handbook 296, Washington: Government Printing Office, 1965.

Livestock and Poultry Inventory. United States Department of Agriculture, LvGn I (64), Washington: Statistical Research Service, 1964.

Patton, B. J., A Brief Description of The Major Soils of West Virginia. Morgantown, United States Department of Agriculture, Soil Conservation Service, 1955.

Pohman, G. G., Land Classification in West Virginia Based on Use and Agricultural Value. Bulletin 284, Agricultural Experiment Station, West Virginia University, Morgantown, 1937. p. 9 ff.

Price, P. H., R. C. Tucker, O. L. Haught, West Virginia Geological Survey. Vol. 10, Geology and Natural Resources of West Virginia, Charleston: Matlicws Printing and Lithograph Co. 1938. p. 12.

Thirtieth Biennial Report Tax Commissioner of West Virginia. Charleston: Mathews Printing and Lithograph Co.

I/nited States Census of Agriculture: 1930, 1940, 1950, 1959, and 1964. Bureau of the Census, Washington: Govermment Printing Office.

West Virginia Agricultural Stalistics, 1964. West Virginia Department of Agriculture, C. R. Bulletin No. 6, Charleston, WV. Va., 1964.

West Virginia soil and IValer Conservation Needs Inventory, The West Virginia Conservation Necds Committee, Morgantown: State Soil Conservation Commiltee, 1961. 


